
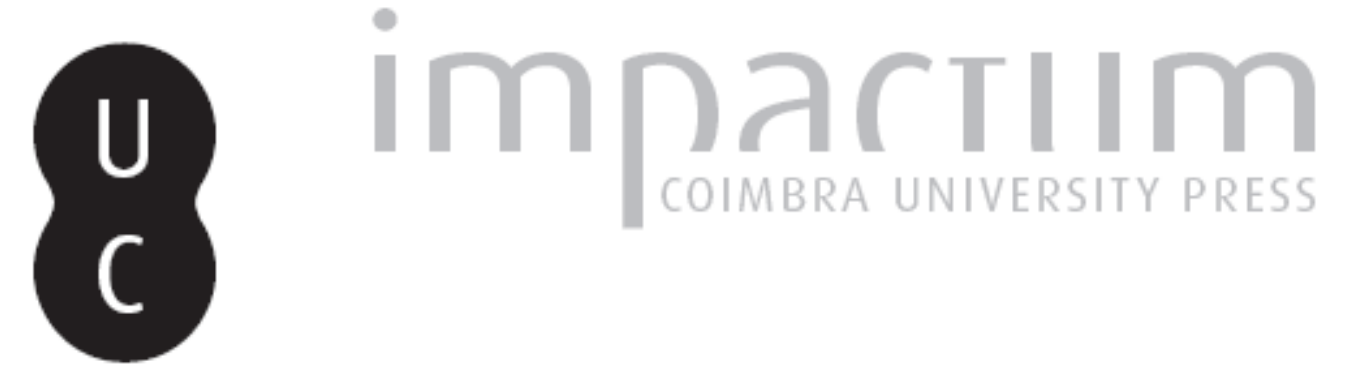

\title{
O controle do poder e a ideia de constituição
}

\section{Autor(es): $\quad$ Coutinho, Pedro de Oliveira}

Publicado por: Universidade Católica de Petrópolis

URL persistente:

URl:http://hdl.handle.net/10316.2/33910

DOI:

DOI:http://dx.doi.org/10.14195/2175-0947_1-1_10

Accessed : $\quad$ 26-Apr-2023 09:03:24

A navegação consulta e descarregamento dos títulos inseridos nas Bibliotecas Digitais UC Digitalis, UC Pombalina e UC Impactum, pressupõem a aceitação plena e sem reservas dos Termos e Condições de Uso destas Bibliotecas Digitais, disponíveis em https://digitalis.uc.pt/pt-pt/termos.

Conforme exposto nos referidos Termos e Condições de Uso, o descarregamento de títulos de acesso restrito requer uma licença válida de autorização devendo o utilizador aceder ao(s) documento(s) a partir de um endereço de IP da instituição detentora da supramencionada licença.

Ao utilizador é apenas permitido o descarregamento para uso pessoal, pelo que o emprego do(s) título(s) descarregado(s) para outro fim, designadamente comercial, carece de autorização do respetivo autor ou editor da obra.

Na medida em que todas as obras da UC Digitalis se encontram protegidas pelo Código do Direito de Autor e Direitos Conexos e demais legislação aplicável, toda a cópia, parcial ou total, deste documento, nos casos em que é legalmente admitida, deverá conter ou fazer-se acompanhar por este aviso.

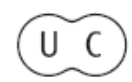



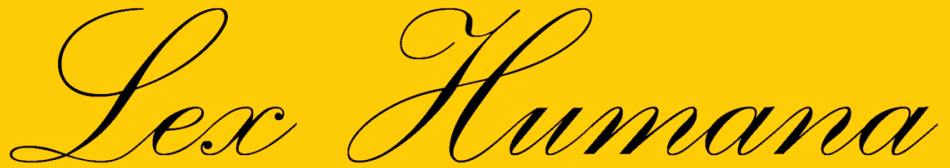

Revista do Programa de Pós-Graduação em Direito da UCP

ISSN(e) 2175-0947

Universidade Católica de Petrópolis Rua Benjamin Constant, 213 - Petrópolis - Centro CEP 25610-130

Tel: (24) 2244-4000 E-mail: lexhumana@ucp.br 


\title{
O CONTROLE DO PODER E A IDÉIA DE CONSTITUIÇÃO ${ }^{1 *}$
}

\author{
Pedro de Oliveira Coutinho
}

\section{Introdução}

Os revolucionários franceses fizeram constar de sua Declaração Universal dos Direitos do Homem e do Cidadão que uma sociedade onde não haja a separação de poderes e não se estabeleçam garantias dos direitos não tem Constituição. ${ }^{2}$ Essa visão histórica, que veio a ensejar o dogma da separação dos poderes, representava uma tomada de posição firme contra o absolutismo, por meio de uma atitude "iluminista anti-historicista" que procurava romper com a tradição. ${ }^{3}$ Foi preciso ter sob a ótica uma determinada concepção de constituição, que se pode dizer substancial.

A idéia que se defende nesse texto tem uma origem diversa dessa herança voluntarista, aproximando-se das idéias inerentes à tradição do constitucionalismo inglês e norte-americano. Sem pretender estabelecer um novo dogma, nos inspiramos nessa máxima revolucionária para estabelecer que no constitucionalismo contemporâneo a idéia de uma Constituição só tem sentido quando ela estabelece um sistema de controle do poder.

Para apresentar as bases de tal pensamento, é preciso antes fixar premissas que possam delimitar o objeto da assertiva, e assim evitar eventuais incongruências e contestações. Tais premissas referem-se ao estabelecimento do tipo de constituição de que se está a tratar, qual o poder que se pretende controlar, e, finalmente, o que vem a significar o controle desse poder. Só $1 \quad{ }^{*}$ Trabalho apresentado no curso de Mestrado em Direito Público da Universidade do Estado do Rio de Janeiro na disciplina Teoria da Constituição, ministrada pelo professor Paulo Braga Galvão.

2 Art.16. "Toda sociedade na qual não não esteja assegurada a garantia dos direitos nem determinada a separação dos poderes não tem constituição" Apud in CAETANO, Marcelo. Direito Constitucional, vol. I. Rio de Janeiro: Forense. 1977, p.238.

3 PALOMBELLA, Gianluigi. Filosofia do Direito. São Paulo: Martins Fontes. 2005, p. 38. 
então será possível atentar para as formas com que se estabelece esse controle na Constituição, em especial na Constituição Brasileira.

\section{Definindo algumas premissas}

2.1 A constituição como Lei Fundamental do Estado Contemporâneo

Para estabelecer nosso conceito de Constituição é preciso afastar o termo dos vários sentidos possíveis do vocábulo, situando-o no campo do Direito ${ }^{4}$. Ainda assim, existe uma genérica compreensão jurídica do fenômeno Constituição que é empregada quando se afirma que todo Estado possui Constituição, entendido o Estado como a sociedade politicamente organizada. Assim é que o professor Charles Howard McIlwain trata do constitucionalismo antigo e moderno, examinando experiências da Antigüidade. ${ }^{5}$ Essas concepções enxergam a constituição como o "conjunto institucional do Estado, a sua forma, o seu governo, em suma, todo o complexo normativo e costumeiro referente ao poder político organizado de uma determinada nação." McIlwain assim se refere à expressão grega politeia:

Significa sobre todo el estado como es en la realidad. Es un término que comprende todas las innumerables características que determinam la naturaleza peculiar de un estado, incluyendo el conjunto de su estructura económica y social, así como lo referente a las cuestiones de su gobierno,

4 Cf. SILVA, José Afonso da. $23^{\mathrm{a}}$ ed. Curso de Direito Constitucional. São Paulo, Malheiros, 2004, p.37, onde constam outros sentidos da palavra constituição, como compleição do corpo humano ou o conjunto de elementos essenciais de alguma coisa; V. também MCILWAIN, Charles Howard, Constitucionalismo Antiguo y Moderno, Madrid: Centro de Estúdios Constitucionales, 1991, p.41.

5 Op. cit. Existe, contudo, uma visão do constitucionalismo antigo como aquele que teria se formado desde fins da Idade Média até o século XVIII, sem incluir a Antigüidade. Cf. CANOTILHO, José Joaquim Gomes. Direito Constitucional e T eoria da Constituição. 2 ed. Coimbra: Almedina. 1998. p.46. 6 FRANCO, Afonso Arinos de Melo. Direito Constitucional: Teoria da Constituição. As Constituições do Brasil. Rio de Janeiro: Forense. 1976. p. 113. 
en el sentido moderno más estricto en que hoy las entendemos. Se trata de un término puramente descriptivo, comprensivo en su significado de las mismas cosas que incluímos en la palabra 'constitución', cuando hablamos en términos generales de la constitución de un hombre o de la matéria. $^{7}$

Essa é a noção de constituição no sentido material, assim definida pelo professor J. H. Meirelles Teixeira:

Em sentido material, vimos que o Estado se manifesta como unidade de poder, e que este deve ser exercido por alguém, segundo certas regras ou métodos, com determinados limites, tendo em vista fins preestabelecidos. Donde todo Estado existir de um certo modo, assumir uma certa fisionomia, uma certa forma, características próprias, e a esse modo de ser de cada Estado denominamos 'Constituição'. Nesse sentido, todo Estado terá sua Constituição. ${ }^{8}$

7 Op. cit. p.45-46. Em tradução livre: "Significa sobretudo o estado como é na realidade. É um termo que compreende todas as inumeráveis características que determinam a natureza peculiar de um estado, incluindo o conjunto de sua estrutura econômica e social, assim como o referente às questões de seu governo, no sentido moderno mais restrito em que hoje as entendemos. Se trata de um termo puramente descritivo, compreensivo em seu significado das mesmas coisas que incluímos na palavra 'constituição', quando falamos em termos gerais da constituição de um homem ou da matéria". Uma outra distinção importante pode ser acrescentada: "Portanto, parece justificado afirmar que, no mundo antigo, a Constituição não tem o status formal que passa a ter nos Estados modernos. Isso não é falso na medida em que ela não é a norma superior do direito público do Estado e, como tal, fundadora e produtora de outras normas jurídicas destinadas a regular a vida política, mas o próprio ser da existência e do funcionamento da Cidade-Estado: sua substancialidade própria." GOYARD-FABRE, Simone. O que é Democracia. Trad. Claudia Berliner. São Paulo: Martins Fontes. 2003. p. 45. 8 TEIXEIRA, J. H. Meirelles. Curso de Direito Constitucional. Rio de Janeiro: Forense Universitária, 1991, p. 42. No mesmo sentido: BONAVIDES, Paulo. Curso de Direito Constitucional. 9 ed. São Paulo: Malheiros, 2000. p. 63. Corresponde, assim, à constituição real e efetiva de que trata Ferdinand Lassale ao tratar da existência dos fatores reais do poder, cf. in A Essência da Constituição. 3 ed. (sem indicação de tradutor) Rio de Janeiro: Líber Juris, 1995. p.47. Com idêntico sentido, mas denominando esse conceito como formal e 
Definitivamente, não é dessa Constituição que nós estamos tratando quando investigamos a sentença posta no início desse trabalho. Interessa-nos o estudo da Constituição já sob o influxo do fenômeno do constitucionalismo, ${ }^{9}$ ou constitucionalismo moderno, que caracteriza o movimento surgido no século XVIII e que veio a tornar possível o conjunto de constituições do mundo ocidental contemporâneo. Pois foi justamente por meio dos ideais do liberalismo político, caracterizado pela busca de contenção do poder absoluto do soberano - não o liberalismo econômico ${ }^{10}$-, que o fenômeno constitucional ganhou expressão na Europa e nas Américas. A Constituição não será apenas a forma de organização do Estado, mas a sua limitação em favor dos direitos do povo. ${ }^{11}$

Se é verdade, como afirma Nelson Saldanha, que na Idade Média

abstrato: ENTERRÍA, Eduardo García de. La Constitucion como Norma y el Tribunal Constitucional. 3 ed. 3 reimp. Madrid: Civitas. 1994. p.43; já sob a denominação de conceito "empírico-descritivo": CANOTILHO, J. J. Gomes. Direito Constitucional e Teoria da Constituição. 2 ed. Coimbra: Almedina, 1998. p.1003. Apresentando versões ampla, média e restrita de constituição material, sendo a ampla aquela aqui referida: MIRANDA, Jorge. Teoria do Estado e da Constituição. Rio de Janeiro: Forense, 2002. pp.214. Uma visão bem distinta é apresentada em KELSEN, Hans. Teoria Pura do Direito. $6^{\mathrm{a}}$ ed. São Paulo: Martins Fontes, 1998. p. 247: "A Constituição é aqui entendida num sentido material, quer dizer: com esta palavra significa-se a norma positiva ou as normas positivas através das quais é regulada a produção das normas jurídicas gerais."

9 TEIXEIRA, J. H. Meirelles. Op. cit. p. 444: "Evidentemente, e como bem acentua Valle Pascual, o que denominamos hoje 'constitucionalismo' é uma fase histórico-política, a fase moderna do Direito Constitucional, pois só o Estado moderno, após a Revolução Francesa e norte-americana (já, portanto, em fins do século XVIII), apresenta-se como Estado constitucional. Melhor, portanto, a seu ver, chamá-lo 'Estado liberal', ou 'Estado de direito', para caracterizá-lo como reação contra o absolutismo." No mesmo sentido: BINENBOJM, Gustavo. A Nova Jurisdição Constitucional. Rio de Janeiro: Renovar, 2001. p. 15.

10 O liberalismo político está preocupado com a garantia dos direitos e liberdades fundamentais, enquanto que o econômico preocupa-se basicamente com a não intervenção do Estado na área econômica. Cf. SOUZA NETO, Cláudio Pereira de. Teoria constitucional e democracia deliberativa: um estudo sobre o papel do direito na garantia das condições para a cooperação na deliberação democrática. Rio de Janeiro: Renovar, p. 21.

11 Entendido o termo aqui em um sentido restrito, dado que nesse período havia escravidão, as classes trabalhadoras praticamente não tinham direitos e as mulheres não gozavam de situação de igualdade. 
o poder foi sempre limitado, repartido, ${ }^{12}$ o fato é que a experiência política da época não conhecia os direitos fundamentais nem havia regras institucionalizadas de divisão de poderes. Foi após o surgimento dos Estados modernos, com unidade política e concentração de poder na figura do soberano, ${ }^{13}$ que surgiu na Europa um conjunto de idéias pregando a contenção desse poder político, com a elaboração de um documento escrito capaz de submeter não só o povo como também o soberano às leis de uma nação. Ou, nas palavras de Canotilho:

Numa outra acepção -histórico-descritiva - falase em constitucionalismo moderno para designar o movimento político, social e cultural que, sobretudo a partir de meados do século XVIII, questiona nos planos político, filosófico e jurídico os esquemas tradicionais de domínio político, sugerindo, ao mesmo tempo, a invenção de uma nova forma de ordenação e fundamentação do poder político. ${ }^{14}$

O próprio Nelson Saldanha esclarece a distinção entre simples divisão de tarefas públicas e a divisão dos poderes:

Em qualquer Estado, incluindo os despotismos do Oriente antigo, verifica-se a existência de um processo de divisão de atribuições, a partir das do monarca (no caso dos absolutismos régios) com os 'magistrados' de determinada espécie, que ditam normas ou dirimem querelas, ou assessoram decisões; mesmo nos casos de extrema concentração ou 'enfeixamento' de funções nas mãos do autocrata, tais funções são passíveis de diferenciação, ainda que não se encontrando legalmente distribuídas entre titulares específicos.

12 Formação da Teoria Constitucional. 2 ed. Rio de Janeiro: Renovar, 2000. p. 17 .

13 FIGUEIREDO, Fran. Metodologia Constitucional. Brasília: Itamarati, 1987. p.7. 
No ocidente moderno, o clamor liberal contra o governo onipresente e o clamor democrático contra o absolutismo dominante levaram a exigências muito definidas no sentido de uma reorganização do esquema do poder governamental: seria preciso distribuir, entre titulares distintos, as tarefas governamentais. ${ }^{15}$

Assim, chegamos ao conceito de constituição no Estado moderno, aquele decorrente do movimento liberal-democrático que procura instituir um governo com base na soberania da nação ou do povo, limitado pelos direitos do homem, com a proteção das liberdades civis e políticas por meio de técnicas instrumentais. ${ }^{16}$ É a Constituição como uma espécie de "certidão de nascimento do Estado Moderno", ${ }^{17}$ capaz de qualificá-lo como Estado Constitucional.

Podemos definir a Constituição assim estabelecida como:

[...]conjunto de normas fundamentais que regulam a atribuição e o exercício do Poder político, definindo a competência dos seus órgãos, as funções específicas destes e os direitos dos indivíduos e das sociedades primárias com força obrigatória para todos os poderes constituídos e vinculativa de seus atos. ${ }^{18}$

Veremos mais adiante que ainda não se pode satisfazer a indagação do início deste trabalho com a definição acima. Será necessário qualificála como Constituição do Estado de Direito Democrático Social para que se

15 O Estado moderno e a separação dos poderes. São Paulo: Saraiva, 1987. p.86.

16 TEIXEIRA, J. H. Meirelles. Op. cit. p. 43.

17 FIGUEIREDO, Fran. Op. cit. p. 1. No mesmo sentido: "Superando, não sem dificuldades, a equivocidade do termo 'direito', a filosofia do direito orientou a reflexão sobre o Poder para uma concepção constitucionalista que realmente construiu o pórtico do estado moderno." GOYARD-FABRE, Simone. Os Princípios Filosóficos do Direito Político Moderno. Trad. Irene A. Paternot. São Paulo: Martins Fontes, 1999. p.100. 
possa admitir que toda constituição tem em seu núcleo, necessariamente, um sistema de controle do poder. Far-se-á uso, então, da constituição em sentido normativo, que deve ter um "conteúdo específico", formando um corpo de normas jurídicas que vinculam o corpo político, estabelecendo limites ao poder, informadas por "princípios materiais fundamentais", como o "princípio da separação dos poderes" e o "controle político e/ou jurídico do poder", entre outros. ${ }^{19}$

\section{$2.2 \mathrm{O}$ conceito de poder}

Não são poucos os estudiosos que afirmam que o fenômeno do poder parece ser irredutível, podendo ser analisado pelos mais diversos ângulos das Ciências Sociais e Econômicas. Mas o âmbito deste trabalho não comporta digressões sobre as diferentes visões dessa categoria, limitando-se aqui ao estudo sob a ótica político-jurídica. ${ }^{20}$

Marcelo Caetano define o poder como sendo "a possibilidade de, eficazmente, impor aos outros o respeito da própria conduta ou de traçar a conduta alheia" ${ }^{21}$ deixando evidente a característica dual do poder, ou seja, a presença do elemento subjetivo vontade e do elemento objetivo capacidade. ${ }^{22}$

19

CANOTILHO, J. J. Gomes, Op. cit. p. 1004.

20 Segundo Diogo de Figueiredo de Moreira Neto, podemos definir assim o mesmo fenômeno: "no sentido antropológico: o poder é visto como um diferencial de capacidade entre os seres humanos, que habilita a vontade a produzir efeitos que não ocorreriam espontaneamente. No sentido sociológico, o poder é a energia social que se transfunde na instituição para instituição para articular a vida coletiva. No sentido político, o poder é o elemento essencial da relação comando/obediência, como energia inter-relacional que move os indivíduos e as coletividades para a realização de suas respectivas finalidades: individuais, grupais, nacionais e metanacionais." V. Poder, Organização Política e Constituição: as relações de poder em evolução e seu controle. In: TÔRRES, Heleno Taveira (coord.), Direito e Poder: Estudos em Homenagem a Nelson Saldanha. São Paulo: Manole, 2005. p.258. Segundo o autor, foi o polonês Ludwig Von Gumplowicz o primeiro a estudar o fenômeno do poder de forma sistemática e distinta no âmbito da teoria política, dando início ao que se denominou de Cratologia. O tema recebe maior desenvolvimento na sua obra Teoria do Poder: sistema de direito político. São Paulo: Revista dos Tribunais, 1992.

$21 \quad$ Op. cit. p. 17.

22 MOREIRA NETO, Diogo de Figueiredo. Op. cit. p. 259. 
Há sempre, pois, uma relação polarizada. ${ }^{23}$ Essa possibilidade se consubstanciaria na imposição a outros da própria vontade, sem resistências, ou na obrigação de condutas alheias. ${ }^{24}$ Essa também parece ser a definição do professor Carl Joachim Friedrich quando sustenta que "alguém tem poder político sobre outro ou outros desde que eles sejam vistos seguindo suas preferências e fazendo aquilo que lhes é mandado em lugar do que fariam por vontade própria", ${ }^{25}$ para, logo a seguir, destacar que o uso habilidoso do poder permite a conversão da coação em consentimento. ${ }^{26}$

$\mathrm{Na}$ medida em que o ser humano vive em sociedade, onde são formados diversos grupos sociais, surge o que se pode denominar de poder social, que é assim definido por Marcelo Caetano:

O exercício do poder social consiste, portanto, em definir normas de conduta dos indivíduos nas suas relações entre si ou com a coletividade e fazer observar essas normas aplicando determinadas sanções previstas para os desobedientes, e em determinar a ação do grupo, nas relações com outras coletividades e com os próprios membros. ${ }^{27}$

Sendo o Estado o grupo social máximo, a princípio tem ele também o seu poder, que pode ser denominado de político ou estatal, e que representa um poder superior ao dos demais grupos sociais existentes em seu interior, justamente o que vem a caracterizar a soberania. ${ }^{28}$ Assim, exerce o Estado o poder político "no desempenho de suas funções, e atuando sobre os membros

23 SALDANHA, Nelson. O Estado Moderno e a Separação de Poderes.

São Paulo: Saraiva, 1987. p. 81.

24 Idem. Ibidem. Bobbio vê o poder como a "capacidade que um sujeito tem de influenciar, condicionar, determinar o comportamento de um outro sujeito" Cf. BOBBIO, Norberto. (org. por Michelangelo Bovero) Teoria Geral da Política. Rio de Janeiro: Campus. 2000, p. 216.

25 Uma Introdução à Teoria Política. Trad. Leônidas Xausa e Luiz

Corção. Rio de Janeiro: Zahar Editores, 1970. p.131. Contudo, reservaremos o qualificativo político ao poder que é exercido pelo Estado.

26 Idem. Ibidem.

27 CAETANO, Marcelo. Op. cit. p. 18.

28 SILVA, José Afonso da. Op. cit. p.107. 
da população para cumprimento de seus fins". ${ }^{29}$

Bobbio vale-se justamente dos meios utilizados para que se obtenham os efeitos desejados como forma de distinguir o poder político como aquele que se vale da força. Diz o pensador italiano: "Uma vez que o poder político se caracteriza pelo uso da força, ele é o sumo poder ou o poder soberano, cuja posse distingue, em toda sociedade organizada, a classe dominante". ${ }^{30}$

Mas é a dependência exclusiva da força que torna esse poder político um mero poder de fato, enquanto que o poder legítimo seria aquele que se baseia no reconhecimento daqueles a quem é dirigido. ${ }^{31}$ Quem nos fornece uma clara diferenciação entre o poder de fato e o poder legítimo é o professor Paulo Bonavides:

Se o poder repousa unicamente na força, e a Sociedade, onde ele se exerce, exterioriza em primeiro lugar o aspecto coercitivo com a nota da dominação material e o emprego freqüente de meios violentos para impor a obediência, esse poder, não importa sua aparente solidez, ou estabilidade, será sempre um poder de fato.

Se, todavia, busca o poder sua base de apoio menos na força de que na competência, menos na coerção do que no consentimento dos governados, converter-se-á então num poder de direito. ${ }^{32}$

Não se pode imaginar um sistema de controle de poderes fora do exercício do poder legítimo, por isso que a Constituição caracteriza o Estado Democrático de Direito. Afinal, o sistema democrático ergue-se em torno de dois princípios básicos: legitimidade dos governantes e a limitação de sua autoridade. ${ }^{33}$ E ao poder é reconhecida uma característica inevitavelmente dinâmica, que conduz a uma destinação natural de expansão que é preciso conter, sob pena de instauração de um governo autoritário. ${ }^{34}$

29 DINAMARCO, Cândido Rangel. A Instrumentalidade do Processo. 4 ed., São Paulo: Malheiros, 1994. p.85, nota de rodapé n 14.

30 Op. cit. p.221.

31 CAETANO, Marcelo, Op. cit. p. 17

32 Ciência Política. 12 ed., São Paulo: Malheiros. 2006, p.115.

33 FRANCO, Afonso Arinos de Melo. Op. cit. p.133.

34 MOREIRA NETO, Diogo de Figueiredo. Op, cit., p.261. 
Do contrário, ter-se-ia uma Constituição meramente formal, ou mesmo uma Constituição-mito, que é desligada da realidade social em mutação, passando a ser um símbolo, cuja finalidade é a de frear o progresso humano, impedindo ou retardando a transformação social. ${ }^{35}$

Vale aditar, ainda, que ao se destacar o controle do poder político não se está a olvidar a existência das demais manifestações do poder no mundo moderno, em especial o poder econômico, que muitas vezes também restringe a liberdade do indivíduo. Há apenas uma limitação do foco do estudo com vistas a demonstrar a evolução do pensamento político como forma de assegurar a liberdade. ${ }^{36}$

\subsection{Sentido de controle do poder}

A palavra controle tem origem francesa, "designando inicialmente um registro formado de uma lista em duas vias: o rol e o contra-rol (rôle

35 FRANCO, Afonso Arinos de Melo. Op. cit. p.117. Para o autor, duas seriam as possíveis conseqüências de sua imposição: ou a revolução, ou o predomínio do regime que impôs a constituição, com a conseqüente supressão da liberdade. Essa concepção se aproxima daquela desenvolvida por Marcelo Neves, denominada Constituição simbólica, que numa de suas vertentes se configura como Constituição álibi, ou seja, aquela cujo texto não apresenta eficácia normativa e vigência social, sendo suas normas reiteradamente violadas pelo aparato estatal, mas que desempenha um papel político-ideológico relevante, eis que serve ao discurso dominante para diminuir as tensões sociais e imunizar o sistema contra alternativas políticas. V. "A constitucionalização simbólica: uma síntese.” Boletim da Faculdade de Direito da Universidade de Coimbra. 20 anos da Constituição de 1976. Coimbra: Coimbra Editora, p.99-131, 2000.

36 Salienta LARENZ, Karl que: "El Estado de Derecho, que ha adoptado como línea diretriz de su própia construción el princípio de control y de limitación del poder, no puede dejar de procurar la vigencia de este principio quando en outro campo se edifica un poder que por su magnitud amenaza la libertad de los demás." Derecho justo....p. 162. 
e contre-rôle)." 37 Assume então um sentido de verificação. ${ }^{38}$ Levado ao idioma inglês, o verbo decorrente do substantivo passa a apresentar três acepções fundamentais: 1) investigar, testar ou verificar; 2) censurar; 3) exercer um poder decisório sobre alguém, regulando suas ações. ${ }^{39}$

Tem-se da conjugação desta origem tanto um sentido forte de dominação, como um sentido mais atenuado de fiscalização ou verificação. A palavra foi logo incorporada aos demais idiomas europeus, inclusive o português, sempre com sentidos próximos ao que acima foi assinalado, embora com bastante diversificação, como domínio, revisão, intervenção, inspeção, vigilância, freio, preponderância, etc..$^{40}$

Admitindo, então, que a Constituição que nos serve é aquela característica do Estado de Direito Democrático Social, onde é preciso realizar plenamente o conteúdo das normas constitucionais, ${ }^{41}$ pode-se afirmar que o sentido de controle é o de um veículo pelo qual se fazem efetivas as limitações do poder. ${ }^{42}$ Esse sentido é unívoco, na mesma medida em que

37

COMPARATO, Fábio Konder; SALOMÃO FILHO, Calixto. O Poder de Controle na Sociedade Anônima. 4 ed. Rio de Janeiro: Forense, 2005. Já Giannini indica a apropriação do termo latino contra rotulum, que indicaria "o exemplar do rol dos contribuintes, dos tributos, dos censos através do qual se verifica a operação do exator." Apud MEDAUAR, Odete. Controle da Administração Pública. São Paulo: Revista dos Tribunais, 1993.

38 Já era utilizada com esse sentido por Montaigne nos seus famosos Ensaios, como anota COMPARATO, Fábio Konder. Op. cit., p.27, nota de rodapé n 4.

39 Idem. p. 27.

40 ARAGON, Manuel. Constitución y control del poder. Buenos Aires: Ciudad Argentina, 1995. p.69-70; COMPARATO, Fábio K. Op. cit. p. 29, que indica, nas páginas seguintes, vários diplomas legislativos nacionais onde o termo teria sido utilizado nas versões forte ou atenuada.

41 "No entanto, a proclamação do ideal constitucionalista só se tornou relevante para a cidadania onde a Constituição se fixou como um padrão (parâmetro) para a jurisprudência, isto é, onde a Constituição foi incorporada à prática do Poder Judiciário ou, ao menos, de um tribunal especializado na verificação dos atos normativos (do Legislativo e do Executivo) ao direito constitucional vigente." LOPES, Júlio Aurélio Vianna. A Invasão do direito: a expansão jurídica sobre o Estado, o mercado e a moral. Rio de Janeiro: FGV, 2005. p. 45-46. 
unívoco é o sentido de Constituição que adotamos. ${ }^{43}$ Ou seja, todas as formas em que se expressa o controle do poder trazem em si o sentido de evitar os abusos do poder, realizando o princípio do equilíbrio do governo, tal como previsto na Constituição. E, assim, não se pode entender uma Constituição democrática sem o controle do poder político.

Contudo, se existe um sentido de fácil percepção, as possíveis formas em que venha a se institucionalizar, assumindo distintas significações, são inúmeras, como se vê no controle de constitucionalidade das leis, no controle de legalidade da Administração Pública ou no controle de oportunidade e conveniência dos atos discricionários, no controle sobre a relevância e urgência na edição de medidas provisórias, no controle exercido pelos Tribunais de Contas e pelo Ministério Público, no controle sobre a indicação de pessoas para ocupar cargos da cúpula dos poderes, e até mesmo no controle da sociedade sobre o poder público. Ou seja, a pluralidade de meios e agentes que realizam o controle, bem como a diversidade de atividades estatais submetidas a controle impedem a conformação de um único conceito de controle do poder, sendo correto afirmar que há vários conceitos de controle no âmbito constitucional. ${ }^{44}$

É importante consignar, ainda, que mesmo que existam diversos conceitos de controle do poder previstos na Constituição, não se pode confundir o controle com outros termos bastante próximos, todavia distintos, como o são a garantia e a limitação.

Para Aragon, a limitação dos poderes estabelecida na Constituição como ocorre na limitação do poder de tributar, no princípio da reserva legal, na previsão de direitos fundamentais imunes até certa medida à interferência estatal - não é suficiente para garantir o governo democrático, por essa razão são necessárias técnicas de controle que tornem efetivas essas limitações. Assim, podemos vislumbrar no constitucionalismo do século XIX formas distintas de limitação do poder, mas que justamente pela ausência ou debilidade de sistemas de controle contribuíram para a crise do modelo liberal de Estado de Direito. No Estado Democrático de Direito, porém, para que se cumpram as limitações faz-se necessário a existência de um efetivo controle dessa limitação. No mesmo sentido a opinião de Karl Larenz: "Para limitar el poder en la medida necesaria existen los controles del poder, porque sin estos controles existe de añadidura el peligro del abuso de poder. Limitación

44 ARAGON, Manuel. Op. cit., p.72. 
y control del poder se coordinan mutuamente." 45

Para limitações não institucionalizadas do poder haveria sistemas correlatos de controle, exercidos pelo povo, pelos grupos de pressão da sociedade civil, pela imprensa, enfim, são controles difusos. Já para as limitações institucionalizadas, os controles também seriam institucionalizados, ou seja, atribuídos a órgãos próprios para exercê-lo. ${ }^{46}$

Entendido dessa forma, tem-se que o controle é uma garantia das limitações estabelecidas no sistema político de cada país, plasmadas na Constituição rígida. Mas deve-se resguardar o termo garantia constitucional para incluir também outras formas de assegurar o respeito à Constituição. ${ }^{47}$ Nesse sentido, podemos citar a regulação do Estado de Sítio e Estado de Defesa.

3 Evolução do pensamento político sobre a separação de poderes

A influência da experiência constitucional britânica

Desde o século XVI desenvolvia-se na Europa a idéia de equilíbrio, girando em torno de um contrapeso de forças opostas, que ia da relação entre exportações e importações até o conhecimento científico. ${ }^{48}$ De fato, a idéia de poder como uma força e do campo social como campo de forças que se opõem é apropriada pelos pensadores dos séculos XVI e XVII a partir 45 Derecho Justo: fundamentos de etica juridica.Trad. Luis Díez Picazo. 1 ed., reimp. Madrid: Civitas, 1993. p. 159. Em livre tradução: "Para limitar o poder na medida necessária existem os controles do poder, porque sem estes controles existe de complemento o perigo do abuso de poder. Limitação e controle do poder se coordenam mutuamente."

46 ARAGON, Manuel. Op. cit. p. 81-82.

47 Idem. p.85-86. Não se confundam aqui as garantias constitucionais com as garantias dos direitos individuais, de que são exemplos os remédios constitucionais do mandado de segurança e do habeas data, entre outros, já que as primeiras envolvem ainda outros institutos destinados a assegurar a efetividade como um todo do texto constitucional.

48 SCHMITT, Carl. Teoria de la Constitución. 1 ed. 2 reimp. Madrid: Alianza, 1996. p. 187. No mesmo sentido: SALDANHA, Nelson. O Estado Moderno... p. 87. Para a idéia de equilíbrio no campo da política externa e conseqüente ausência de um único Estado dominante, V. WATSON, Adam. $A$ Evolução da Sociedade Internacional. Brasília: Universidade de Brasília, 2004. p.282-284. 
de uma noção da mecânica física, que tem grande desenvolvimento a partir do Renascimento e da Reforma, e que pode ser comprovada pelas idéias desenvolvidas por Hobbes no Leviatã. ${ }^{49}$

Para além dessa influência científica sobre o pensamento político, o certo é que a filosofia política inicialmente preocupada com uma repartição das funções do Estado tem início na Inglaterra, onde desde a Idade Média vinham se desenvolvendo institutos e instituições que limitavam o poder político do soberano. Assim, o modelo dos denominados check and balances surge entre os pensadores políticos a partir da própria experiência política inglesa de governo equilibrado, com o firme propósito de assegurar a liberdade, ou seja, como mecanismo destinado a permitir a liberdade civil. Realmente, os modos de controle do poder são nesse contexto engrenagem instrumental necessária para permitir o equilíbrio do exercício do poder. ${ }^{50}$

Assim é que o desenvolvimento das instituições políticas inglesas permitiu a formação de uma concepção da lei como regra geral, que obriga a todos ${ }^{51}$ e também uma concepção plural do poder. ${ }^{52}$ Essa concepção envolvia a participação de outros atores além do soberano no exercício do poder político, antes demonstrando uma confusão que uma verdadeira separação de poderes. ${ }^{53}$ De toda forma, o fato é que tal característica do exercício do poder impunha algum tipo de controle ao poder político, e que vai pouco a pouco se transformando, durante o século XVIII, de modo a atingir o que se convencionou chamar de constituição bem equilibrada, onde se organiza o funcionamento de um governo bem equilibrado. ${ }^{54}$

O primeiro autor a tratar de forma mais direta da questão da

49 DELACAMPGAGNE, Christian. A Filosofia Política Hoje. Rio de Janeiro: Jorge Zahar Editor, 2001. p.52. No mesmo sentido: BASTOS, Celso Ribeiro. Curso de Teoria do Estado e Ciência Política. 5 ed. São Paulo: Celso Bastos Editor, 2002, p.151/152; LOWENSTEIN, Karl. Teoria de la Constitución. Barcelona: Ariel, 1976. p. 54.

$50 \quad$ ARAGON, Manuel. Op. cit. p. 21.

51 "La distinción más importante y fundamental que resulto de ahi fue la distinción de la Ley como uma norma permanente, obligatoria para todos, incluso para el proprio legislador, y, por lo tanto, general, que no puede quebrantarse para un caso particular, respecto de las restantes ramas de la actividad de voluntad estatal." SCHMITT, Carl.. Teoria de la Constituición... p.186.

52 ARAGON, Manuel. Constitucion... p.16-17.

53 Idem. p. 18.

54 Idem. p.18-19. 
separação dos poderes foi John Locke, que publica seu Segundo Tratado sobre o Governo Civil $^{55}$ em 1690, onde o autor distingue três tipos de poder: o legislativo, o executivo e o federativo, sendo o último relativo aos aspectos externos do Estado, relacionados com a celebração de tratados e alianças. ${ }^{56}$ Dada a evidente ligação entre os dois últimos, fato reconhecido por Locke, e a negação da existência do Judiciário como poder autônomo, tem-se em verdade uma bipartição do poder. ${ }^{57}$

Ao apenas sugerir que os poderes legislativo e executivo fiquem separados,${ }^{58} \mathrm{sem}$ advogar tal necessidade, e também por olvidar a situação do poder judiciário, Locke não foi capaz de apresentar uma teoria da separação dos poderes que pudesse ser plenamente aplicada aos demais países da Europa.

$\mathrm{Na}$ Inglaterra, quem efetivamente divulga uma teoria do equilíbrio do poder baseada em controles recíprocos é Bolingbroke, que assinalou, ao longo da primeira metade do século XVIII, o que se convencionou chamar de sistema de freios e contrapesos, check and balances. ${ }^{59}$

55

Assinala Marcelo Caetano que a obra originariamente tinha a denominação Two Treatises of Government sendo acrescentada a expressão Civil a partir de uma edição de 1884 , como forma de afastar o tema do governo eclesiástico. Op. cit. p. 232.

56 DELACAMPAGNE, Christian. Op. cit. p. 50. Karl Lowenstein sublinhou que a obra de Locke quebrou para sempre o poder do Estado. Op.cit. ,p. 60. 57 BOBBIO, Norberto. Locke e o Direito Natural. 2 ed. Brasília: Ed. Universidade de Brasília, 1997. p. 233 e 234. Segundo o autor italiano, para Locke a imparcialidade dos juízes seria garantida pela generalidade das leis, que afetam a todos de modo uniforme, por essa razão seria o Legislativo o garantidor dessa imparcialidade, confundindo-se nele o Judiciário. Tanto o legislador como o juiz seriam os responsáveis pelo estabelecimento do direito. Op. cit. p. 232. Interpretação contrária foi feita por Paulino Jacques, para quem, em função da natureza das coisas, Locke compreendia o poder judicial inserido no poder executivo. Curso de Direito Constitucional. 5 ed. Rio de Janeiro: Forense, 1967. p. 110.

58 LOCKE, John. Segundo Tratado sobre o Governo. São Paulo: Abril Cultural, 1978. p.91. (Coleção Os Pensadores)

59 ARAGON, Manuel. Op. cit. p.19; BONAVIDES, Paulo, Ciência ..., p.150. Rosah Russomano aponta a primazia de Harrington, no seu Curso de Direito Constitucional apud BASTOS, Celso Ribeiro. Op. cit. p.183. Contra: SALDANHA, Nelson. O Estado Moderno... p.95, que, com apoio em George Sabine, afirma que o pensamento de Harrington se aproximava mais ao esquema 
A consagração do tema na obra de Montesquieu

Foi sem dúvida Montesquieu o grande divulgador da idéia de uma divisão dos poderes políticos entre o Executivo, o Legislativo e o Judiciário ${ }^{60}$, estabelecendo uma "repartição horizontal" decorrente da diferenciação funcional. ${ }^{61}$ Influenciado pela experiência política britânica e sem dúvida pela leitura de Locke, entre outros teóricos, Montesquieu desenvolveu sua doutrina no livro Do Espírito das Leis, de 1784, ao tratar da Constituição da Inglaterra, no capítulo VI do Livro Décimo Primeiro. É ilustrativa de sua doutrina a seguinte passagem:

Tudo estaria perdido se o mesmo homem ou o mesmo corpo dos principais, ou dos nobres, ou do povo, exercesse esses três poderes: o de fazer leis, o de executar as resoluções públicas e o de julgar os crimes ou as divergências dos indivíduos. ${ }^{62}$

E a idéia de equilíbrio entre os poderes é logo depois esboçada da seguinte forma:

Eis, assim, a constituição fundamental do governo de que falamos. O corpo legislativo sendo composto de duas partes, uma paralisará a outra por sua mútua faculdade de impedir. Todas as duas serão paralisadas pelo poder executivo, que o será, por sua vez, pelo legislativo.

Estes três poderes deveriam formar uma pausa ou inação. Mas como, pelo movimento necessário das coisas, eles são obrigados a caminhar,

organizatório das cidades-Estado gregas.

60 SILVA, José Afonso da. Curso de Direito Constitucional Positivo. 23 ed. São Paulo: Malheiros, 2004. p.109. No mesmo sentido: BASTOS, Celso Ribeiro. Curso de Teoria do Estado e Ciência Política. 5 ed. São Paulo: Celso Bastos Editor, 2002. p.180. Com opinião contrária ao ensino tradicional, Christian Ruby afirma que Montesquieu limitava-se a pregar a proibição do acúmulo de funções jurídicas do Estado. Introdução à Filosofia Política. 1 ed., $1^{\text {a }}$ reimp. São Paulo: Unesp, 1998. p.82.

61 CANOTILHO, J. J. Gomes. Op. cit. p. 498.

62 MONTESQUIEU, Barão de La Brède e de [Charles Louis de Secondat]. Do Espírito das Leis. São Paulo: Abril Cultural, 1973. p.157. (Coleção Os Pensadores). 
serão forçados a caminhar de acordo. ${ }^{63}$

Somente os governos moderados, como o da Inglaterra, seriam capazes de garantir a liberdade política, o que só se obtém pela via do controle recíproco entre os poderes políticos. Cada poder tem, assim, tanto a faculdade de estatuir sobre as matérias de sua competência como a faculdade de impedir que os outros poderes pratiquem atos exorbitantes, quer dizer, que violem a lei ou o equilíbrio constitucional. ${ }^{64}$ De fato, a conexão entre as atividades dos poderes políticos divididos é parte importante de sua doutrina $^{65}$ mas, para alguns críticos, aparentemente ele não percebeu toda a complexidade do sistema de controles recíprocos existente na Inglaterra, que não se limitava à mera faculdade de impedir, mas exigia interconexões obrigatórias para o desempenho das funções estatais. ${ }^{66}$ Essa crítica feita a Montesquieu pode ser atribuída, em parte, ao fato de que na época em que conheceu de perto a experiência política inglesa, entre 1729 e 1731, o regime político da ilha já caminhava para o sistema de gabinete, não comportando perfeita distinção entre Parlamento e Executivo, mas sim caracterizando um sistema de colaboração de poderes, fato que não teria sido percebido por

63

Idem. Ibidem. p. 161. É interessante observar que a passagem transcrita não esclarece de que forma o Poder Judiciário participaria desse sistema de controles, embora isso soe implícito. Montesquieu afirma, algumas linhas antes, que o Poder Judiciário é um poder nulo, o que soa misterioso para Carl Schmitt. Op. Cit. p. 188. Uma resposta sobre essa definição de poder nulo é-nos fornecida por Albert Calsamiglia, quando trata de definir a metodologia de julgamento dos casos difíceis criada por Ronald Dworkin. Segundo o professor espanhol, ao pretender retirar toda a discricionariedade judicial na resolução dos problemas são resolvidos pelos juízes, eles submetem-se à lei e ao direito, e, portanto, não exercem poder político, quer dizer, o poder político é nulo. Ensayo sobre Dworkin. Prólogo a DWORKIN, Ronald. Los derechos em serio. Trad. Marta Guastavino. 1 ed., 3 reimp. Barcelona: Ariel, 1997. p.21.

64 CAETANO, Marcelo. Op. cit. p. 236.

65 "O equilibrio constitucional dos poderes não é apresentado por

Montesquieu como o princípio decisivo da democracia, mas como condição sine qua non de uma política de liberdade. [...]A distinção dos poderes legislativo, executivo e judiciário, necessária para sua colaboração equilibrada, cria um obstáculo, explica Montesquieu, para o autoritarismo que, seja a forma que adote - o da massa ou de um chefe -, afeta a liberdade devido a sua inevitável arbitrariedade." GOYARD-FABRE, Simone. O Que é Democracia... p. 138. 66 ARAGON, Manuel. Op.cit.,, p. 22-23. 
Montesquieu. ${ }^{67}$ Entretanto, Montesquieu jamais pregou a absoluta separação entre os poderes, como mais tarde chegou-se a proclamar em França. ${ }^{68}$

A separação de poderes e a divisão de poderes

Nesse momento, parece oportuno consignar o que vem a distinguir, portanto, a separação de poderes e a divisão de poderes, já que nem todos os autores fazem essa distinção. ${ }^{69}$ Assim, a divisão de poderes significa a atribuição de funções governamentais a órgãos diferentes, de modo a evitar a concentração de poderes ${ }^{70}$, enquanto que a idéia de separação de poderes não admitiria, em tese, interferências recíprocas. Quer dizer, são as funções em que se divide o exercício do poder que são primordialmente afetadas a um determinado órgão, caracterizando o que se pode denominar de "especialização funcional", sendo certo que cada um desses órgãos deverá ser estruturado de maneira que venha a desempenhar sua função de modo independente, ou seja, sem subordinação a algum dos demais poderes, ainda que sujeitando-se a controles, fato esse que vem a caracterizar a "independência orgânica."”1 Sob esses dois fundamentos ergue-se a forma de organização jurídica do poder político do Estado moderno.

Nenhuma das idéias, porém, significa a efetiva quebra das características básicas do poder político, quais sejam, a unidade, a indivisibilidade e a indelegabilidade, pois essas retratam apenas formas de

67 BONAVIDES, Paulo. Ciência Política... p.147. No mesmo sentido: LOWENSTEIN, Karl. Op.cit. 60.

68 Nesse sentido assevera GOYARD-FABRE, Simone: "Esse esquema constitucional, segundo o qual 'o poder pára o poder', tem como conseqüência o controle mútuo e recíproco dos poderes legislativo, executivo e judiciário. Essa autolimitação é própria de um 'governo moderado', o único que pode aplicar uma política de liberdade." O Que é Democracia...p.139.

69 Por exemplo, TEIXEIRA, José Horácio Meirelles. Op. cit., p. 572.

70 SILVA, José Afonso da. Curso.... p.108. Com visão diversa, Carl Schmitt sustenta que a separação significa um isolamento completo, que serve de ponto de partida para posterior organização e regulação dos poderes, admitindo, então, algumas vinculações recíprocas, enquanto a divisão seria uma distinção dentro de um dos poderes, como se deu na divisão do Legislativo americano entre Senado e Câmara dos Deputados. Teoria...p.188 e 189.

SILVA, José Afonso da. Op. cit. ,p. 109. 
exercício das funções do Estado. ${ }^{72}$

A Constituição norte-americana e o sistema de freios e contrapesos

No Federalista, Madison reconheceu a enorme influência da obra de Montesquieu na elaboração da Constituição dos Estados Unidos da América de 1787. De outro lado, ao referir-se à Constituição inglesa que inspirara o autor francês, identifica ele a ausência de uma total separação de poderes. ${ }^{73}$

Se é certo que a Constituição de Massachussetts de 1780 chegou a prever expressamente uma separação rígida dos poderes, fato inédito até então, o mesmo texto trazia formas de controle recíprocos que afastavam a idéia que inicialmente se poderia formar. ${ }^{74}$

Como se procurou demonstrar acima, não há incompatibilidade, portanto, entre a afirmação da influência das idéias de Montesquieu sobre os constituintes norte-americanos e a mesma influência advinda da história constitucional inglesa, que definira o sistema de controles recíprocos como necessário para um bom governo, aquele que assegura a liberdade política. Assim é que a Constituição Federal elaborada em 1787 veio a consagrar o sistema de freios e contrapesos, esboçado pelo constitucionalismo inglês, adaptando-o ao novo regime republicano estabelecido, com a adoção do bicameralismo, e obrigando a colaboração entre os poderes. Esse sistema logo veio a ser reforçado com a adoção explícita do controle de constitucionalidade das leis, a partir do julgamento pela Suprema Corte do caso Marbury vs. Madison, em 1803, cuja doutrina foi elaborada pelo Chief Justice Marshall. ${ }^{75}$

Jefferson definia o sistema de freios e contrapesos como "aquele em que os poderes estão de tal forma repartidos e equilibrados entre os diferentes órgãos que nenhum pode ultrapassar os limites estabelecidos pela Constituição sem ser eficazmente detido e contido pelos outros."

$72 \quad$ SILVA, José Afonso da, Op. cit. p.107.

73 BONAVIDES, Paulo. Ciência Política... p.148 e MADISON, James et alli., Os Artigos Federalistas. Rio de Janeiro: Nova Fronteira. 1993, p. 331, 332 e 333.

74 ARAGON, Manuel. Op. cit. p. 28.

75 Trecho do julgamento pode ser encontrado na coletânea elaborada por SWISHER, Carl Brent. Decisões Históricas da Corte Suprema. Rio de Janeiro: Forense, 1964. p.9-14.

$76 \quad$ Apud CAETANO, Marcelo. Op. cit. p. 237. 
Em resumo, assim se comporta o sistema:

O Legislativo rejeita o 'veto' do Executivo, procede por impeachment contra o executivo e aprecia as indicações do Executivo para provimento de altos cargos públicos; o Legislativo, ainda, fixa o número de membros do Judiciário, limita a sua jurisdição, e procede por impeachment contra os altos magistrados; o Executivo, à sua vez, veta resoluções do Legislativo, e nomeia os membros do Judiciário; e, por fim, o Judiciário declara a inconstitucionalidade dos atos do Legislativo e a ilegalidade dos do Executivo. ${ }^{77}$

Assegurava-se, desse modo, que a divisão de poderes significava interdependência de poderes, não sendo suficiente o controle do povo sobre os governantes para permitir o gozo da liberdade. ${ }^{78}$

Cerca de 100 anos após a elaboração da constituição americana, assim era definida a separação de poderes ali vigente:

[...] é uma máxima na ciência política que, para conseguir o legítimo reconhecimento e proteção dos direitos, os poderes do governo devem ser classificados segundo a sua natureza, e que para tal execução cada classe de poder deve ser confiada a um diferente departamento do governo. Esta disposição dá a cada departamento uma certa independência, que opera como um freio sobre a ação dos outros que poderiam usurpar os direitos e a liberdade do povo, e torna possível o estabelecer e o reforçar as garantias contra quaisquer tentativas de tirania. Por isto, temos os freios e os contrapesos do governo, supostos como essenciais à liberdade

77 JACQUES, Paulino. Op, cit. p. 113, com grifos no original. No mesmo sentido, com alguns acréscimos: BONAVIDES, Paulo. Ciência Política...p. 151 e 152. Rejeita-se aqui, portanto, uma visão que equipara a doutrina dos freios e contrapesos à teoria da separação dos poderes, como se vê em TEMER, Michel. Elementos de Direito Constitucional. 11 ed. São Paulo: Malheiros, 1995. p. 113. Apontando um denominador comum, qual seja, a luta contra o arbítrio, mas a distinção das duas noções: SALDANHA, Nelson. O Estado Moderno e a Separação de Poderes. São Paulo: Saraiva, 1987. p.96.

CAETANO, Marcelo. Op. cit. p. 29. 
das instituições. ${ }^{79}$

E não foi diferente ao longo do século XX e início deste novo século, a demonstrar que para o constitucionalismo norte-americano a idéia de controle do poder é um elemento inseparável do conceito de Constituição. ${ }^{80}$

\subsection{A Revolução Francesa e a teoria da separação dos poderes}

$\mathrm{O}$ ataque ao absolutismo na França inspira-se numa leitura de Montesquieu $^{81}$ e de outros pensadores, especialmente Jean-Jacques Rosseau, que termina por privilegiar um acentuado destaque para a distinção dos poderes do Estado, com raras interferências recíprocas, que veio a caracterizar o princípio da separação de poderes na forma indicada no art.16 da Declaração dos Direitos do Homem e do Cidadão.

Os revolucionários adotaram a concepção de lei como fruto da vontade geral, considerando o Direito como produto imediato da decisão do povo ou de seus representantes. Adicionando-se a isso a previsão de respeito aos direitos individuais, tal como prevista na Constituição de 1791, tem-se uma forma específica de Estado que se qualifica como fundada na soberania popular, democraticamente estabelecida, com tríplice limitação do poder político: material, pela proteção dos direitos, funcional, pela divisão dos poderes, e temporal, pela previsão de eleições periódicas. ${ }^{82}$

Cabe anotar, porém, que a noção de soberania popular desenvolvida por Rousseau não leva a sustentar o regime democrático como aquele que deve caracterizar o governo. Ele distingue a soberania popular do regime de governo, como enfatiza Goyard-Fabre:

Nesse sentido, para retificar o erro corrente que faz de Rousseau, à luz da Revolução Francesa, o porta-voz do regime democrático, é preciso primeiro lembrar que, na problemática política

79 COOLEY, Thomas M.. Principios Gerais de Direito Constitucional nos Estados Unidos da América. Campinas: Russel, 2002. p. 51.

80 ARAGON, Manuel. Op.cit. p. 30.

81 A atribuição a Montesquieu do desenvolvimento de um modelo teórico extremamente rígido de separação de poderes foi denunciada por diversos autores do século XX como um mito. CANOTILHO, J. J. Gomes. Op. cit. p. 108.

82 ARAGON, Manuel. Idem. p. 24 e 25. 
que ele formula e examina, a soberania do povo é o fundamento de toda sociedade política e não o critério do governo democrático.

[....]

Com efeito, o contrato social faz nascer a sociedade civil, que, por isso, enraíza-se sempre na vontade geral do povo. Mas embora a soberania do povo conote assim o critério de todo Estado ou República, ele não determina por si só nenhum modelo de governo. ${ }^{83}$

De fato, ao proclamar a lei como produto direto da vontade popular, como verdadeiro dogma, pois fruto da razão soberana, não se permitia o estabelecimento de um sistema de freios e contrapesos, restando a limitação de poderes apenas na medida em que a própria Assembléia Popular assim o definisse, ou seja, apenas se admitia a auto-limitação do poder político. ${ }^{84}$ Afinal, se a soberania é indivisível, os poderes são soberanos, e não se faz possível a interferência de um sobre a atividade do outro. O perigo que tais idéias podem trazer para a liberdade política foi bem apreendido por Cláudio Pereira de Souza Neto:

Interpretado hobbesianamente, contudo, o contrato social de Rousseau pode ser entendido em termos de impossibilidade de se restringir o princípio majoritário. Vale dizer, qualquer que seja o conteúdo do texto legal, desde que tenha resultado da vontade da maioria, deve ser obedecido e aplicado pelo judiciário. No limite, até mesmo as leis do terror deveriam ser consideradas como legítimas, já que decorrentes da vontade geral. ${ }^{85}$

83 GOYARD-FABRE, Simone. O Que é Democracia. p.154 e 156.

84 ARAGON, Manuel. Op. cit. p.25.

85 Jurisdição Constitucional, Democracia e Racionalidade Prática. Rio de Janeiro: Renovar. 2002, p. 26. Vendo na concepção de Rousseau sobre a vontade geral uma imagem totalitária: LOWENSTEIN, Karl. Op. cit. p. 61. Ainda assim, suas idéias tinham um profundo caráter contestatório do regime da época, como deixam ver as vicissitudes da obra: "Impressa em Amsterdam em abril de 1762, proibida na França em maio seguinte, condenada pelo Parlamento de Paris em 
Sabe-se que a desconfiança nutrida em relação aos juízes do Antigo Regime, por servidão aos interesses reais, e a concepção da atividade jurisdicional como mera aplicação mecânica da lei ${ }^{86}$ contribuíram para a forte aversão dos franceses ao controle judicial da constitucionalidade das leis. ${ }^{87}$

$\mathrm{Na}$ Constituição jacobina de 1793, a idéia de que o poder supremo pertence ao povo é levada a extremos, e já não se tem verdadeiramente uma separação rígida dos poderes, pois em seu lugar prevalece a força da Assembléia única, capaz de impor sua vontade, o que termina por desnaturar a idéia aparentemente democrática inicial, levando a um governo forte e sem controles. $^{88}$

A prática demonstrava, assim, que a concepção francesa de separação de poderes, ainda que admitindo certo grau de limitação, não oferecia garantias suficientes para impedir que a ação do poder político viesse a macular as liberdades políticas. ${ }^{89}$

O século XIX e a crise da idéia de controle do poder

As marcantes influências que a Revolução Francesa trouxe para o pensamento político europeu do século XIX foram vitais para a consagração da teoria da separação dos poderes, influenciando a elaboração das novas cartas políticas no velho continente, inclusive sendo adotadas nas constituições das nações que se libertaram do colonialismo no continente 9 de junho, queimada no dia 11, queimada de novo no dia 19 em Genebra,..." V. DELACAMPAGNE, Christian. Op. cit., p.60.

86 O próprio Montesquieu afirmava: "Porém, se os tribunais não devem ser fixos, os julgamentos devem sê-lo a tal ponto, que nunca sejam mais do que um texto exato da lei. Se fossem uma opinião particular do juiz, viver-se-ia na sociedade sem saber precisamente os compromissos que nela são assumidos." Cf. $O p$. cit. p.158. Parece evidente que o perigo da consequiência afirmada não conduz necessariamente à premissa adotada.

87 ARAGON, Manuel. Op. cit.,p. 25. Esse fato vem aos poucos se transformando, a partir dos últimos 20 anos, por meio da proteção aos direitos fundamentais, consubstanciando o que se convencionou chamar de doutrina Badinter. Cf. LOPES, Júlio Aurélio Vianna. A Invasão do Direito: A Expansão Jurídica sobre o Estado, o Mercado e a Moral. Rio de Janeiro: FGV, 2005. p.49. 88 CAETANO, Marcelo. Op. cit. p. 239.

89 ARAGON, Manuel. Op. cit. p.25 e 26. 
americano..$^{90}$ Por outro lado, a versão filosófica então predominante entre os teóricos foi essencial para o desprestígio da idéia de controle de poderes como forma de obtenção do equilíbrio do governo.

Esse período é bem sintetizado pelo jusfilósofo Palombella:

À luz da evolução histórica e filosófica subseqüente, a equação lei-direitos tenderá a ser desenvolvida em sentido unilateral, ou seja, com uma perda do caráter originário da questão dos direitos, bem como com sua passagem à posição secundária em relação à tutela da instituição Estado e da lei como fonte globalizante do direito. Em todo o continente europeu permanecerá substancialmente axiomática a submissão do juiz à lei, sendo indireta a referência aos direitos, e haverá uma tendência progressiva à atenuação do aspecto de garantia em favor do estatalismo. Assim o problema da ordem institucional, como pressuposto da própria afirmação dos direitos, prevalecerá sobre a exigência apresentada pelo jusnaturalismo, ou seja, a prioridade dos direitos. ${ }^{91}$

Na França, em especial, verificava-se uma ausência de amarras tanto dos atos do Executivo, livre do controle por parte do Judiciário sobre os atos políticos, e mesmo de boa parte dos administrativos, ${ }^{92}$ como também do Legislativo, dada a ausência de controle de constitucionalidade das leis. ${ }^{93}$ A única forma admitida de controle de tais poderes tinha por base a

$90 \quad$ Afirma CANOTILHO que o princípio "transformou-se mesmo em ratio essendi da Constituição.” Op. cit.,p. 498. Na mesma linha segue Nelson Saldanha, para quem no século XIX formou-se "uma espécie de entusiasmo pelo constitucionalismo como fórmula política, como atitude e como mentalidade." Formação da Teoria...p.156.

91 PALOMBELLA, Gianluigi. Op. cit. p. 42, onde, a seguir, o autor esclarece que o fenômeno não atingia a Inglaterra, onde prevalecia o entendimento de que a organização do poder não era suficiente para a garantia dos direitos.

92 ARAGON, Manuel. Op. cit. p. 31. Aqui o autor sustenta-se na lição de Hariou.

93 Nesse sentido a lição de FAVOREAU, Louis: “A partir da Revolução 
vontade popular, já que as eleições seriam, para muitos teóricos, a garantia de ausência de um governo absoluto ou despótico. ${ }^{94}$ Esse grau de imunidade vai se verificar ao longo dos ciclos constitucionais que a França irá viver ao longo do século XIX.

A exceção que confirma a regra consiste na teoria de Benjamin Constant, que continha a previsão de um poder neutro, o pouvoir royal, capaz de impor o equilíbrio entre os demais poderes, representado pela figura do soberano. Obviamente, esse poder teria de sobrepor-se aos demais, como forma de impor o equilíbrio desejado. ${ }^{95}$ Esse poder, porém, não passou da fase de teorização na França, embora tenha servido de inspiração para a instituição do Poder Moderador na Constituição Brasileira de 1824. ${ }^{96}$

$\mathrm{Na}$ Alemanha, de outro lado, ante a fragmentação política então vivida e a série de eventos tormentosos ocorridos no início do século XIX, desenvolveu-se uma teoria que atribuía ao rei a titularidade da soberania, identificando o Parlamento como um órgão limitador dessa soberania. Tal idéia impunha um frágil controle político e um praticamente inexistente controle jurídico do Executivo. ${ }^{97}$

Por outro lado, alguns teóricos passaram a identificar a soberania com a figura do Estado, não de seu monarca, onde a liberdade só seria possível no interior do Estado, donde decorre a existência dos direitos individuais pelo reconhecimento estatal dos mesmos, e apenas na extensão em que são de 1789, ao longo do século XIX e início do século XX, o dogma rousseauniano da infalibilidade da lei se impôs e raramente foi posto em dúvida." As Cortes Constitucionais. São Paulo: Landy. 2004, p. 20.

$94 \quad$ ARAGON, Manuel. Op. cit. p. 32 e 33.

95 MORAES FILHO, José Filomeno. "Separação de poderes no Brasil pós-88: princípio constitucional e práxis política.” In: SOUZA NETO, Cláudio Pereira, et al. Teoria da Constituição: estudos sobre o lugar da política no Direito Constitucional. Rio de Janeiro: Lumen Juris, 2003. p. 157. No mesmo sentido: SALDANHA, Nelson. O Estado Moderno... p.100. Veja-se que a função de solucionar conflitos entre outros poderes, como um árbitro, é atribuída ao tribunal constitucional alemão pela Lei Fundamental de Bonn, assim como ao tribunal constitucional italiano pela respectiva constituição, mas sem que em nenhum dos casos isso represente qualquer supremacia. Cf. LOWENSTEIN, Karl. op. cit. p. 321 , que assinala os perigos dessa atuação, por ele denominada de judicialização da política.

96 SILVA, José Afonso da. Op. cit. p. 75; BONAVIDES, Paulo. Ciência Política .... p. 156.

97 ARAGON, Manuel Op. cit. p. 34. 
reconhecidos. ${ }^{98}$ Nesse panorama, Ihering desenvolve o entendimento de que é preciso que o Estado seja controlado pelo direito, ainda que ele venha a ser criado pelo Estado. Na esteira dessa afirmação, Jellinek vai desenvolver a teoria da autolimitação do Estado, dizendo que a atividade do Estado é limitada pelo Direito, que ele próprio estabelece voluntariamente, na medida em que constitui-se em uma pessoa jurídica, e, para manter-se como tal, deve obrigatoriamente submeter-se ao Direito. ${ }^{99}$ A idéia de divisão e equilíbrio do poder está ausente da teoria jurídica estatal então desenvolvida.

Esse panorama vai engendrar a noção de uma Constituição como mera ordenação do Estado, sem qualquer força normativa, ${ }^{100}$ aproximando do conceito de constituição material afastado no início deste trabalho. Nesse contexto se compreende a constatação de Jellinek no alvorecer do século XX:

El desarollo de las Constituciones muestra, a pesar de que todavia no se aprecie suficientemente, el enorme significado de esta enseñanza: que las proposiciones jurídicas son incapaces de dominar, efectivamente, la distribuición del poder estatal. Las fuerzas políticas reales operan según sus propias leyes que actúan independientemente de cualquier forma jurídica. ${ }^{101}$

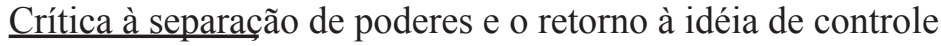
98 Nessa época, a expressão Estado de Direito chega a ser tida como pleonástica, pois haveria uma identificação entre Estado e Direito. SOUZA NETO, Cláudio Pereira de. Teoria Constitucional...p.38.

99 FARIAS, José Fernando de Castro. A Teoria do Estado no Fim do

Século XIX e no Início do Século XX. Rio de Janeiro: Lumen Juris, 1999. p.52-

53. Segundo o autor, além dessa forma de legitimação formal, Jellinek atribui ao Estado uma finalidade, qual seja, desenvolver a civilização, cf. p. 54.

100 ARAGON, Manuel. Op. cit. p.35.

101 JELLINEK, Georg. Reforma y Mutacion de la Constitucion. Madrid:

Centro de Estúdios Constitucionales, 1991. p.84. Em tradução livre: "O desenvolvimento das Constituições mostra, apesar de que ainda não se aprecie suficientemente, o enorme significado deste ensinamento: que as proposições jurídicas são incapazes de dominar, efetivamente, a distribuição do poder estatal. As forças políticas reais operam segundo suas próprias leis que atuam independentemente de qualquer forma jurídica." 
Contra essa noção rígida e isolada da divisão funcional do Poder Político que caracterizou o positivismo ${ }^{102}$ emerge uma gama de críticas no início do século XX, fruto de novas idéias político-jurídicas que respondem a diversas mudanças sociais, econômicas e culturais que afetavam o Ocidente. ${ }^{103}$

Kelsen, que propõe um positivismo renovado ${ }^{104}$, já que pretende se distanciar do modelo anterior, que se pode denominar como conceptualismo, ${ }^{105}$ anota com precisão:

O conceito de 'separação dos poderes' designa um princípio de organização política. Ele pressupõe que os chamados três poderes podem ser determinados como três funções distintas e coordenadas do Estado, e que é possível definir fronteiras separando cada uma dessas três funções. No entanto, essa pressuposição não é sustentada

102 No campo jurídico, vale transcrever a seguinte observação: "A Escola da Exegese revela, assim, através do culto da lei, uma grande influência do pensamento liberal, em especial da teoria da separação dos poderes, sobre a metodologia positivista. A doutrina da separação dos poderes demarcava a separação entre política e direito, que resulta na neutralização política do poder judiciário.[...] Está sempre contida nessas formulações a noção de que uma metodologia jurídica restrita aos termos legais se coaduna com a idéia de governo limitado ou moderado." Cf. SOUZA NETO, Cláudio Pereira de. Op.cit. p. 82 e 87. 103 Sobre o assédio crítico ao liberalismo político nesse período, Nelson Saldanha aponta os fenômenos do irracionalismo, do pessimismo, do militarismo e da massificação. Cf. O Estado Moderno...p. 102.

104 Afirma-se que o modelo dinâmico do direito apresentado por Kelsen caracteriza-se como sistema normativista, pois passa a existir uma preocupação com a produção das normas jurídicas. Cf. SOUZA NETO, Cláudio Pereira de. $O p$. cit. p.110.

105 Característica do período racionalista do século XIX é a contundente afirmação de HEGEL: "Só o conceito pode conduzir a esse conhecimento, devendo abster-se de participar nas discussões todos aqueles que têm a divindade por inconcebível e o conhecimento da verdade por vã tentativa. Não poderá aspirar à consideração filosófica o que diga em seus discursos indigestos e edificantes com os seus sentimentos e os seus entusiasmos." Cf. Princípios da Filosofia do Direito. Lisboa: Guimarães, 1990. p.252. 
pelos fatos.

[...]

É impossível atribuir a criação de Direito a um órgão e a sua aplicação (execução) a outro, e modo tão exclusivo que nenhum órgão venha a cumprir simultaneamente ambas as funções.

[...]

Portanto, foi um erro descrever o princípio fundamental da monarquia constitucional como 'a separação de poderes'. As funções originariamente combinadas na pessoa do monarca não foram 'separadas', mas antes divididas entre o monarca, o parlamento e os tribunais. [...] A significação histórica do princípio chamado 'separação dos poderes' encontra-se precisamente no fato de que ele opera antes contra uma concentração que a favor de uma separação de poderes. ${ }^{106}$

Sua grande contribuição para o estabelecimento de mecanismo de controle do poder será o desenvolvimento do controle concentrado de constitucionalidade, resultante do projeto de Constituição da Áustria, de 1920. ${ }^{107}$ De fato, se a Constituição regulava não só a produção das normas gerais, como também o conteúdo das futuras normas jurídicas, ${ }^{108}$ tinha de contar com um método de controle da produção destas mesmas normas jurídicas, sob pena de tornar-se inútil. ${ }^{109}$ A sugestão da criação de um Tribunal Constitucional tem por objetivo ver "garantida efetivamente"110 a

106 KELSEN, Hans. Teoria Geral do Direito e do Estado. 2 ed. 1 reimp. São Paulo: Martins Fontes, 1995. p. 263 e 274.

107 FAVOREAU, Louis. Op. cit. p.17, que acrescenta ser este o modelo europeu de controle de constitucionalidade das leis. Cabe reconhecer, contudo, que um esboço da idéia de um Tribunal Constitucional que realizasse o controle de constitucionalidade das leis já fora sugerida por Emmanuel Joseph Sieyès, durante o período revolucionário. V. BINENBOJM, Gustavo. Op. cit. p.24.

108 KELSEN, Hans. Teoria Pura...p.249.

109 Manuel Aragon aponta, porém, para a construção do sistema não como forma de estabelecer um limite ao poder do Estado, mas sim pela lógica inerente ao seu sistema normativo. Op. cit. p. 37.

110 KELSEN, Hans. Teoria Geral...p. 158. 
aplicação das regras constitucionais à legislação:

O órgão legislativo considera-se, na realidade, um criador livre do Direito e não um órgão de aplicação do Direito, ligado à Constituição, quando na verdade o é apenas teoricamente, ainda que em medida relativamente restrita. Não é portanto com o Parlamento que podemos contar para conseguir sua subordinação à Constituição. É a um órgão diferente dele, independente dele, e conseqüentemente também a uma autoridade estatal, que é preciso encarregar da anulação dos atos inconstitucionais - isto é, uma jurisdição ou tribunal constitucional. ${ }^{111}$

Parece evidente que um controle não só de procedimento mas também de fundo implicava na atribuição de uma tarefa não só jurídica mas também política a tais tribunais, ${ }^{112}$ o que permitiria o ataque a tal ideal via defesa da separação de poderes. Kelsen pretendeu afastar tal crítica com a teoria do legislador negativo, segundo a qual o Tribunal Constitucional, ao anular a legislação inconstitucional, impõe uma lei, mas sem o caráter de livre criação que caracteriza a ação do Legislativo, pois totalmente determinada pela Constituição. ${ }^{113}$

Karl Lowenstein afirmava que somente o liberalismo constitucional identificava a separação dos poderes com a liberdade individual, e que essa idéia de separação dos poderes apenas expressava a necessidade de distribuir e controlar o exercício do poder político, fruto que foi da técnica de representação da vontade do povo. ${ }^{114}$

Após a experiência do combate aos regimes totalitários na $2^{\mathrm{a}}$ Guerra Mundial, as práticas destinadas a estabelecer algum tipo de efetivo controle

111 Apud. FAVOREAU, Louis. Op.cit. p.24.

112 Nesse sentido a afirmativa de CAPPELLETTI, Mauro. O Controle Judicial de Constitucionalidade das Leis no Direito Comparado. Porto Alegre: Sérgio Antônio Fabris, 1984. p.114.

113 FAVOREAU, Louis. Op. cit., p.24. Assim enuncia Kelsen sua tese: "Se a afirmação, corrente na jurisprudência tradicional, de que uma lei é inconstitucional há de ter um sentido jurídico possível, não pode ser tomada ao pé da letra. $\mathrm{O}$ seu significado apenas pode ser o de que a lei em questão, de acordo com a Constituição, pode ser revogada não só pelo processo usual, quer dizer, por uma outra lei, segundo o princípio lex posterior derogat priori, mas também através de um processo especial, previsto pela Constituição.” Teoria Pura....p. 300. Sobre o tema da legitimidade da jurisdição constitucional, objeto de alguns estudos recentes na doutrina brasileira consulte-se a obra já citada de Gustavo BINENBOJM.

114 Op. cit. p. 56, 58 e 59. 
do poder passam a ganhar maior dimensão, e se restabelece a busca pelo governo moderado, qualificado por restrições e limites regulares, capazes de permitir o pleno desenvolvimento das liberdades individuais e sociais. Seja através de previsão expressa nas Cartas Constitucionais surgidas nesse período, como a Lei Fundamental de Bonn, seja através da construção prática dos operadores jurídicos, ergue-se um verdadeiro sistema de restrições efetivas ao poder, dando início ao que se convencionou chamar de Estado Democrático e Social. ${ }^{115}$

Além da triste influência das conseqüências do fascismo, foi no pósguerra que os Estados ocidentais passaram a desempenhar grande número de atividades até então excluídas de seu campo de competência pelas restrições do Estado liberal, com intervenção no domínio econômico, incremento das ações de assistência social, regulação do jogo do mercado, entre outras características do chamado Welfare State. Esse incremento das ações estatais exigia que se estabelecessem novos métodos de controle para evitar o abuso das autoridades, com interferências ilegítimas na seara da liberdade dos cidadãos, ainda mais em um contexto de democracia pluralista. ${ }^{116}$

Os controles frágeis do estado liberal não serviam para essa finalidade. Além de revigorar e criar novos modos de controles recíprocos de poderes, era necessário ampliar as possibilidades de controle social do poder, realizado através de sindicatos, imprensa, associações profissionais, igrejas, etc. ${ }^{117}$

4. Uma nova função estatal: a função de controle

Foi tamanha a relevância que os mecanismos de controle passaram a ter para a realização da força normativa da Constituição, que surgiu uma teoria de que além das tradicionais três funções dispostas na obra de Montesquieu - a que há muito já se somara uma quarta, resultante da divisão da função executiva entre função de governo e administrativa ${ }^{118}$-, haveria

115 ARAGON, Manuel. Op. cit. p.39-40.

116 Idem. Ibidem. p. 40. Igualmente Bachof, Otto. Jueces y constitución. Trad. Rodrigo Bercovitz Rodriguez-Cano, 1 ed., reimp. Madrid: Civitas, 1987. p. 58: "En el Estado Social moderno, el caráter necesario que en general tiene el Estado para el hombre, la casi total dependencia de éste frente al aparato estatal exige correlativamente un control total de este aparato."

117 BASTOS, Celso Ribeiro. Op. cit. p. 186.

118 SILVA, José Afonso da. Op. cit. p. 108. 
uma função específica de controle. O principal teórico desta teoria foi Karl Lowenstein, que tratou do tema de forma sistemática ainda na década de 50 do século passado.

Comentando a famosa sentença proferida por Lord Acton, que afirmava que o poder tende a corromper e o poder absoluto tende a corromper absolutamente, Lowenstein demonstra a importância que a idéia de controle do poder tem para sua teoria:

Con el fin de evitar esse peligro siempre presente, que es inmanente a todo poder, el Estado organizado exige de manera imperativa que el ejercicio del poder político, tanto en interés de los detentadores como de los destinatarios del poder, sea restringido y limitado. Siendo la naturaleza humana como es, no es de esperar que dichas limitaciones actúen automaticamente, sino que deberán ser introducidas en el proceso del poder desde fuera. Limitar el poder político quiere decir limitar a los detentadores del poder; [...] Un acuerdo de la comunidad sobre uma serie de reglas fijas que obligan tanto a los detentadores como a los destinatarios del poder, se há mostrado como el mejor médio para dominar y evitar el abuso del poder político por parte de sus detentadores. ${ }^{119}$

Após apontar para a superação do dogma da equiparação entre o

119 LOWENSTEIN, Karl. Op. cit. p.29. Em tradução livre: “Com o objetivo de evitar esse perigo sempre presente, que é imanente a todo poder, o Estado organizado exige de maneira imperativa que o exercício do poder político, tanto no interesse dos detentores como dos destinatários do poder, seja restringido e limitado. Sendo a natureza humana como é, não é de se esperar que ditas limitações atuem automaticamente, senão que deverão ser introduzidas no processo do poder desde fora. Limitar o poder político quer dizer limitar os detentores do poder [...] Um acordo da comunidade sobre uma série de regras fixas que obrigam tanto aos detentores como aos destinatários do poder, se mostrou como o melhor meio para dominar e evitar o abuso do poder político por parte dos detentores do poder." 
constitucionalismo e a separação dos poderes, ${ }^{120}$ Lowenstein afirma que é preciso então substituir este "esquema mental" enraizado no pensamento político por uma nova análise da dinâmica do exercício do poder, e propõe uma nova divisão tripartida: $1^{\circ}$ ) a decisão política fundamental, onde são eleitos o sistema político a vigorar em uma nação; $2^{\circ}$ ) a execução da decisão fundamental, repartida pelas funções legislativa, executiva e judicial; e $3^{\circ}$ ) o controle político. ${ }^{121}$

Sobre esta última função, que constituiria o núcleo da nova divisão, ${ }^{122}$ Lowenstein afirma que seu mecanismo mais eficaz é justamente a atribuição de diferentes funções estatais a diferentes órgãos do Estado, o que termina por obrigá-los a cooperar para atingir as metas governamentais que lhes são atribuídas, ao mesmo tempo que a cada um desses órgãos é reconhecido o poder de controle sobre os demais ${ }^{123}$ o que, em suma, caracteriza o sistema de freios e contrapesos.

Além da repartição de funções, a função de controle do poder incluiria formas de controle em que o controlador atua com independência e discricionariedade, como seriam o voto de desconfiança do parlamento sobre o governo, ou o direito do governo parlamentar dissolver o parlamento, o direito do eleitorado de afastar uma lei aprovada pelo legislativo em plebiscito, o veto presidencial a um projeto de lei, etc.. ${ }^{124}$

Para que o sistema de controle do poder se faça eficaz, garantindo um governo responsável ${ }^{125}$ é preciso consagrar as técnicas de controle na própria Constituição, agora elevada à condição de supremacia sobre o ordenamento jurídico. ${ }^{126}$ Afinal, instituições destinadas a controlar o poder não nascem e operam pos si mesmas. ${ }^{127}$

Para verificar a existência de um Estado Democrático Constitucional seria preciso apreciar a existência da distribuição do poder por diferentes órgãos, submetidos cada um deles a um efetivo sistema de controle, sendo que a principal ferramenta de controle reside na possibilidade do controle popular, já que, afinal de contas, é no povo que reside o fundamento do poder 120 Idem. p. 54.

121 Idem. p. 62, 63, 66,67.

122 Idem. p. 68.

123 Idem. p.68-69.

124 Idem. p.70.

125 Idem. p.71.

126 Ibidem.

127 Idem. p. 149. 
político. ${ }^{128}$

Tratando especificamente dos controles do poder, Lowenstein divide os controles como sendo inter-órgãos e intra-órgãos, ambos incluídos no controle horizontal do poder, enquanto o controle vertical se aplicaria no sistema federativo. Como formas de controles inter-órgãos o autor aponta as respectivas influências recíprocas que existem entre os quatro detentores do poder, que ele afirma serem o governo, o parlamento, os tribunais e o eleitorado. Já o controle intra-órgãos se daria dentro da esfera de um dos três órgãos estatais detentores de poder. ${ }^{129}$

Ainda que se rejeite o abandono da teoria da separação de poderes proposta pelo autor, embora mitigada sob a forma de uma divisão dos poderes, sem uma rígida distância entre eles, o fato é que não se pode negar a proeminência dos diversos mecanismos de controle do poder político no constitucionalismo dos últimos 70 anos, estabelecidos como forma de assegurar a eficiência de um sistema democrático de governo, de que foi exemplo a criação em larga escala das cortes constitucionais na Europa Ocidental do pós-guerra, e como vem ocorrendo nas últimas décadas na Europa do Leste. No Brasil, além da existência de diversos mecanismos de controle recíproco, foram aperfeiçoadas instituições dotadas de certa independência que visam a garantir a efetiva atuação dos sistemas de controle. ${ }^{130}$ Em resumo, não há instituição integrante dos poderes que integram o Estado que não exerça alguma forma de controle, e, portanto, que não desempenhe, ao lado de suas funções típicas, também a função de controle.

\section{A teoria da separação de poderes hoje}

A doutrina dos últimos 40 anos é unânime em apontar para a fragilidade da idéia de uma rigidez de separação de poderes. Afinal, a prática demonstrara ser inteiramente inviável essa separação absoluta entre os poderes $^{131}$ pois nenhum deles é em si mesmo soberano ${ }^{132}$ tendo se verificado, 128 Ibidem.

129 Idem. p. 232. Para uma crítica da inclusão do controle exercido pelo eleitorado como característico de um controle inter-órgãos, v: ARAGON, Manuel. Op. cit. p. 83, nota de rodapé n ${ }^{\circ} 33$, cujo argumento será desenvolvido no item 5. 130 Como ocorreu com o Ministério Público e o Tribunal de Contas.

131 CAETANO, Marcelo. Op. cit. p. 245.

132 BASTOS, Celso Ribeiro. Op.cit. p. 184. 
ao longo da história constitucional, uma "perda gradativa da pureza de cada uma das funções do Estado", ${ }^{133}$ do que constituiriam exemplos mais relevantes a prática parlamentarista, em que há uma "simbiose" dos poderes Legislativo e Executivo, ${ }^{134}$ bem como os casos em que um dado poder do Estado é incumbido de desempenhar tarefas tradicionalmente da competência de outro poder, como ocorre com as atividades administrativas instrumentais desempenhadas pelo judiciário e pelo legislativo, ou com a atribuição de competência legislativa ao Executivo, em decorrência da necessidade de rapidez e tecnicidade na normatização de determinados assuntos. ${ }^{135}$

Realmente, não se observou o abandono puro e simples da doutrina da divisão dos poderes por nenhum dos Estados ocidentais, pelo menos do ponto de vista formal. ${ }^{136}$ As três "funções clássicas continuam insubstituíveis", o que se verifica facilmente pelo histórico constitucional brasileiro. ${ }^{137}$

Desse modo, o princípio da separação dos poderes, recebido apenas como divisão das funções do Estado, apresenta-se como um "princípio organizatório fundamental", não consubstanciando um "dogma de valor atemporal", mas sim como princípio "histórico". ${ }^{138}$ Vislumbra-se, assim, um "movimento de acomodação da teoria clássica a novas realidades". ${ }^{139}$ Diz mesmo Marcelo Caetano que o problema de saber quais ou quantos devam ser os órgãos ou sistemas de órgãos em que se reparte o poder político do 133 Idem. Ibidem.

134 LOWENSTEIN, Karl. Op. cit. p.55.

135 Esse fenômeno complexo vem recebendo a denominação de deslegalização, com variantes em função do quadro constitucional dos países, podendo ocorrer via atos regulamentares autônomos ou por atos com força de lei. 136 Basta lembrar que durante o último período autoritário brasileiro, que se estende de 1964 a 1985, o Legislativo funcionou, assim como o Judiciário, ainda que sob rígido controle do Executivo, sujeitos ambos, a qualquer tempo, a medidas coercitivas e punitivas. A manutenção do princípio nesse período foi justamente qualificado como homenagem do vício à virtude por MORAES FILHO, José Filomeno. Op. cit., p. 153 .

137 BASTOS, Celso Ribeiro. Teoria...p. 186. Interessante sugestão é lançada por Nelson Saldanha, para quem a formulação de um esquema organizacional geométrico do poder político, isto é, sob a forma tripartite, teria origem nas tradições culturais que vêm desde as primeiras civilizações, e a tendência para as trilogias, como ocorre com a trindade teológica. V. O Estado Moderno e... p. 109. 138 CANOTILHO, J. J. Gomes. Op. cit. p. 499. Christian Delacampagne denomina-o de princípio regulador. Op. cit. p.56.

139 BASTOS, Celso Ribeiro. Teoria...p. 187. 
Estado passa a ser mera questão de "arte política", que varia de acordo com critérios concretos de cada ordenamento constitucional. ${ }^{140}$

Nesse sentido, a divisão de poderes soa mais técnica do que a separação de poderes. Mas ao reconhecer-se o caráter instrumental do princípio, admitindo-se o seu emprego mesmo em regimes autoritários, onde a divisão se faz meramente formal com o pretexto de manutenção de aparências, em busca de alguma legitimidade externa, fica evidenciado que sem um mecanismo de reforço do sistema, capaz de assegurar a efetiva independência funcional e orgânica de cada um dos poderes, não se pode pretender a realização do Estado Social Democrático de Direito.

Por essa razão se impõe como essencial à consecução de uma Constituição característica do Estado Democrático de Direito a efetiva conjugação da divisão dos poderes com a previsão e a atuação concreta de mecanismos diversos de controle do poder. Só assim será possível empregar a fórmula da divisão dos poderes no sentido atribuído pelo Tribunal Constitucional alemão (Bundesverfassungsgericht), quando se definiu que o seu significado "reside na distribuição de funções, na interdependência dos três poderes, e no equilíbrio do poder resultante dessa interação." ${ }^{141}$

No Brasil, o princípio da separação de poderes vem previsto na Constituição Federal de 1988, mantendo a tradição das constituições anteriores, inclusive na fórmula prevista no art. $2^{\circ}$, que afirma que os três poderes são independentes e harmônicos entre si. ${ }^{142} \mathrm{~A}$ independência, como já se viu, ${ }^{143}$ pressupõe ausência de subordinação tanto funcional como orgânica, de modo a que um dos poderes não fique juridicamente submetido a qualquer dos outros.

Já a harmonia pode ser definida em dois sentidos: tanto no respeito às prerrogativas de cada um dos poderes, importando no dever de não invadir competências alheias, como também pela existência do sistema de freios

140 Op. cit. p. 244. No mesmo sentido: SALDANHA, Nelson. O Estado Moderno...p.123. V. ainda: BACHOF, Otto. Op. cit., p. 58: "No existe ningún esquema patenteado de división de poderes que pueda funcionar em todas las épocas y bajo los más diversos supuestos sociales."

141 KIMMINICH, Otto. "Jurisdição constitucional e princípio da divisão de poderes”. Revista de Direito Público, São Paulo, n. 92, 1989, p.22.

142 O professor J. H. Meirelles Teixeira chega mesmo a utilizar a expressão "harmonia e independência dos poderes" como sinônimo de divisão ou separação de poderes. Op. cit., p. 572.

143 V. item 3.3 supra. 
e contrapesos. Há mesmo quem afirme a existência de um princípio da harmonia, que assim pode ser conceituado:

[...],que não significa nem o domínio de um pelo outro nem a usurpação de atribuições, mas a verificação de que, entre eles, há de haver consciente colaboração e controle recíproco (que, aliás, integra o mecanismo), para evitar distorções e desmandos. ${ }^{144}$

Nesse contexto é que se deve interpretar o princípio da separação de poderes estabelecido na Constituição Federal, ou seja, não como a já combalida versão rígida do princípio da separação de poderes, mas sim como uma divisão de poderes que admite, em prol da segurança jurídica dos indivíduos e da viabilização do exercício da democracia, um sistema complexo de controles recíprocos.

Por isso, a previsão contida no art. $60, \S 4^{\circ}$, inciso IV da Constituição Federal, que tornou a separação de poderes cláusula pétrea, não se admitindo proposta de emenda constitucional com tendência a abolir esse sistema, tem como pressuposto o fato de que os poderes estatais já sofrem uma série de limitações e controles estabelecidos no próprio texto constitucional. Podese afirmar, portanto, que a idéia central do princípio reside na contenção do arbítrio, e menos na idéia de uma garantia de competências exclusivas para cada órgão do Estado, permitindo-se a edificação de um sistema em que se preveja a "interpenetração de funções estatais", como forma de impor a cooperação dos órgãos políticos do Estado. ${ }^{145}$ Vale aqui transcrever a precisa lição do professor Otto Kimminich:

O controle recíproco, a limitação e moderação do poder do Estado dele resultantes não têm por escopo o enfraquecimento ou a incapacitação do Estado para o cumprimento de suas funções, mas visam, sobretudo, à proteção do indivíduo e à preservação de seus direitos e interesses no complexo emaranhado de normas e dos órgãos incumbidos de sua aplicação. ${ }^{146}$

De outro lado, forçoso reconhecer a vinculação da separação dos poderes com o princípio da legalidade, já que apenas com um Legislativo independente será possível submeter a todos por meio da lei, e apenas um 144 SILVA, José Afonso da. Op. cit. p. 111.

145 SOUZA NETO, Cláudio Pereira. Teoria Constitucional...p. 31-32.

146 Op. cit. p. 23. 
Judiciário imparcial pode assegurar a defesa dos direitos legalmente situados frente ao poder político ou social. ${ }^{147} \mathrm{Ou}$ seja, é preciso que além de um "governo das leis" tenha-se também um governo submetido às leis. ${ }^{148}$

\section{As formas de controle do poder na Constituição}

Podemos distinguir três grandes formas de exercício do controle do poder nas constituições: o controle social, o controle político e o controle jurídico.

A classificação de Manuel Aragon enquadra como controle jurídico aquele que seria exercido com caráter objetivado e fundado em razões jurídicas, de modo sempre necessário, cujo desempenho é atribuído a um órgão independente e imparcial, dotado de competência técnica para resolver questões jurídicas. Já o controle político seria fundado em critérios subjetivos, em que haja uma relação de hierarquia entre o controlador e o controlado, de modo voluntário. ${ }^{149}$

Assim, no controle político a limitação é imposta pelo próprio controlador, como no caso do controle do Parlamento sobre o governo do primeiro-ministro. Já no controle jurídico a limitação vem da norma abstrata, elaborada pelo legislativo, e a atividade de controle seria apenas o exercício da atualização dessa limitação pré-estabelecida, como ocorre com o controle da legalidade dos atos da Administração Pública pelos tribunais. ${ }^{150}$ Isso não esconde o fato de que essas limitações impostas pelas normas jurídicas trazem em si relações de poder, portanto, questões políticas. Mas é justamente a forma do exercício do controle que diferencia as hipóteses. Nega-se, assim, que a simples regulação de uma forma de controle torne o exercício desse controle um controle jurídico. O direito, pois, limita-se a traçar o procedimento e definir as competências do exercício do controle político, na sua função de garantia institucional, mas não entra no cerne do substrato utilizado para o controle em si.

6.1 Controle jurisdicional como modelo de controle jurídico

147 Essa associação é feita expressamente em SALDANHA, Nelson. $O$ Estado Moderno e ...p.112.

148 SOUZA NETO, Cláudio Pereira. Teoria Constitucional ...p.35.

149 Op. cit., p.82-83.

150 Idem. p. 84. 
Desenvolvendo o tema, Aragon afirma que o controle jurisdicional do poder é um controle jurídico justamente porque seus parâmetros são retirados do sistema normativo pré-existente, que não fica à disposição do julgador para decidir se deve ou não aplicá-lo. Afinal, as limitações já estão postas pelo sistema normativo, não são criadas pelo órgão de controle. Será exercido esse controle com base em razões jurídicas, por isso a possibilidade de sua verificação e reforma por órgãos judiciais superiores. Verificando-se a infração à ordem jurídica, terá o controlador de impor a sanção prevista, ainda que seja a de inconstitucionalidade do ato submetido a controle.

Ganha especial relevância o caráter jurídico-normativo da Constituição, em que o texto constitucional é encarado não mais como mero programa político, e sim como um sistema normativo que é perfeitamente aplicável pelos magistrados na resolução dos casos concretos, ou seja, torna-se o centro de toda a ordem jurídica, e, para que se mantenha o caráter objetivado do controle jurídico, é preciso desenvolver critérios objetivos de interpretação da Constituição.

São essas características que levam o professor espanhol a afastar de tal classificação o controle administrativo, ou seja, aquele exercido pela própria Administração Pública sobre a sua atividade, pois estariam ausentes a objetividade e a imparcialidade das decisões de controle. ${ }^{151}$

Concorda-se parcialmente com tal assertiva, na medida em que o controle administrativo parece insuficiente para assegurar o respeito à legalidade, ou para garantir a defesa dos direitos fundamentais, enfim, permitir o efetivo controle do poder público, sem que, contudo, isso importe em afastar a atividade de controle administrativo de mais próxima legalidade e imparcialidade possível. De outro lado, e sem pretender aqui estenderse sobre o tema, haverá sempre um limite ao controle jurídico da atividade administrativa, por razões diversas, e aqui o controle administrativo revelará toda a sua importância, pois incidirá onde o juiz não tem condições de agir. ${ }^{152}$

O objeto desse controle jurídico incluiria todo o tipo de ato praticado pela administração pública, para aferir sua conformidade com o direito, em um sentido amplo a ponto de abranger até mesmo a produção de normas jurídicas, incluindo o controle de constitucionalidade das leis, e até das reformas constitucionais através de emendas. Assim, fica demonstrado que o que se controla não são os órgãos públicos, ou as pessoas que desempenham 151 Op. cit. .p.94.

152 O próprio Manuel Aragon não chega a enquadrar o controle administrativo como forma de controle político. 
funções públicas, mas os próprios atos praticados por tais agentes. ${ }^{153}$

Outra questão interessante diz respeito aos controles prévios de constitucionalidade das leis, exercidos por algum órgão estatal, podendo mesmo ser denominado de Tribunal Constitucional, como ocorre na França, em que o objeto de controle é ainda um projeto de lei, e, assim, um ato que não produz efeitos jurídicos, e o seu resultado não será a nulidade do ato, mas o impedimento à produção de efeitos. Isso permite afastar a qualificação dessa função como jurisdicional. ${ }^{154} \mathrm{O}$ que importa, porém, não é se a função é tipicamente jurisdicional, e sim se o controle é jurídico, o que pode ser afirmado ante o exercício do controle por razões de ordem jurídica, sobre um ato estatal juridicamente relevante, ainda que não produza efeitos, com base no sistema normativo anteriormente fixado, praticado por um órgão independente e imparcial, especializado nessa tarefa, apresentando como resultado um efeito sancionatório. ${ }^{155}$

\subsection{O controle parlamentar como modelo de controle político}

A principal característica do controle político consiste no fato de que a limitação é posta pelo próprio controlador, podendo se afirmar que tratar de um controle de oportunidade, já que não há um cânone fixo, e sim um parâmetro disponível para o controlador. São razões de conveniência política que vão fundamentar a decisão do controlador, pois, como afirma Aragon: "el órgano o el sujeto controlante es libre para ejercer o no el control y que, de ejecerse, el resultado negativo de la valoración no implica, necessariamente, la emissión de uma sanción." 156

É preciso lembrar, porém, que se trata de um controle institucionalizado, diferenciando-se do controle social, razão pela qual há de haver expresso reconhecimento pela ordem jurídica de tal competência controladora. ${ }^{157}$ Por se tratar de uma forma de controle externo, essa competência deverá ser definida na própria Constituição.

Assim, dotados de competência juridicamente fixada, exercerão

153 Op. cit. p.94-95.

154 Op. cit. p. 97. O autor propõe a denominação de função consultiva.

155 Op. cit. p.98.

156 Idem., p.92. Em livre tradução: “[...] o órgão ou o sujeito controlador é livre para exercer ou não o controle, e que, de exercer-se, o resultado negativo da valoração não implica, necessariamente, a emissão de uma sanção."

157 Idem. p. 145. 
órgãos e agentes sua atividade de controle político, submetendo a controle não exatamente os atos dos controlados, mas os próprios órgãos e agentes a eles submetidos, ainda que o controle se realize eventualmente de forma indireta, através dos atos por eles produzidos.

A liberdade de exercício do controle, como antes afirmada, significa que ainda que se faça referência a normas constitucionais ou infraconstitucionais, não há critérios próprios de aferição da interpretação lançada pelo controlador. Tem-se como exemplo claro o controle parlamentar sobre a urgência e relevância das medidas provisórias. A interpretação que prevalece no Supremo Tribunal Federal é a de que cabe exclusivamente ao Congresso Nacional, e hoje também às Assembléias Legislativas, definir se tais espécies normativas preenchem ou não o critério constitucional. Vejamos a conclusão do professor espanhol:

En resumidas cuentas, en el control político, aun en los supuestos en que el ordenamiento se refiere a un canon normativo de comprobación, la libertad de valoración de ese canon, las razones de oportunidad que la presiden, la liberdad de decisión (política) mediante la cual el control se manifiesta, hacen que el parâmetro sea enteramente disponible para el agente del control. Se trata siempre, pues, de una decisión política basada en razones políticas. ${ }^{158}$

O controle parlamentar representa o paradigma desse tipo de controle, pois a simples submissão de atos estatais ao seu exame já configura o controle político. Nesse campo, o direito e a política se associam de forma quase a confundir-se. Como antes afirmado, para que haja o exercício do controle político é necessário que haja norma prevendo essa atividade, mas isso não transforma o controle político em um controle jurídico. Ou, por

158 Op. cit. p. 152. Em livre tradução: "Em resumo, no controle político, ainda nas hipóteses em que o ordenamento se refere a um cânone normativo de comprovação, a liberdade de valoração desse cânone, as razões de oportunidade que a presidem, a liberdade de decisão (política) mediante a qual o controle se manifesta, fazem que o parâmetro seja inteiramente disponível para o sujeito do controle. Trata-se sempre, pois, de uma decisão política baseada em razões políticas." 
outras palavras, a juridicização desse controle não transforma sua natureza. ${ }^{159}$ O que há, de fato, é a regulação da competência, do procedimento, dos instrumentos de controle político.

\subsection{Controle social como atividade não institucionalizada}

Seguindo o critério aqui adotado, o controle social retrata o controle dos poderes políticos efetuado de forma não institucionalizada. A sua operação se dá de maneira difusa, por meios e modos diversos, incumbindo ao direito, em especial à Constituição, prever garantias que permitam o seu livre exercício. Tal se dá, primordialmente, pela tutela dos direitos fundamentais, já que a liberdade do cidadão, e aqui o termo é tomado em seu sentido material, é pressuposto necessário para a própria existência do controle social.

Constituem formas de controle social do poder político a atividade da imprensa livre e a manifestação da opinião pública, incluindo os grupos organizados por interesses específicos, ou seja, manifestações da sociedade organizada por meios protegidos pelo direito, mas não amplamente regulados, como ocorre no estabelecimento das competências dos controles antes analisados. ${ }^{160}$

\section{Conclusão}

A Evolução do pensamento político-jurídico foi capaz de construir um sistema em que a necessária repartição de tarefas públicas, presente em qualquer forma de organização política estatal, impunha a distinção entre órgãos dotados de poder político, cada um titular de competências específicas, determinando diferentes formas de composição e formação de seus quadros, para evitar a concentração de poder. Mas a simples divisão de poderes demonstrou ser insuficiente para garantir a liberdade dos indivíduos, implicando o isolamento das diversas esferas públicas, além do Idem. p. 159.

160 Tais formas de controle constituem o que Charles Cadoux denomina de contra-poderes, destinados a conter a tendência monopolizadora da ação governamental. Apud CASTRO, Flávia Viveiros de. O Princípio da separação dos poderes. In: Manoel Messias Peixinho, Isabella Franco Guerra e Firly Nascimento Filho (orgs). Os Princípios na Constituição de 1988. 2 ed., Rio de Janeiro: Lumen Juris, 2006. p. 144-145. 
distanciamento entre o governo e a sociedade. Esse caráter instrumental da separação de poderes, funcionando como critério estruturante do moderno Estado ocidental, foi capaz de conviver com diferentes formas históricas de organização política, ${ }^{161}$ algumas delas hoje francamente inaceitáveis pela consciência política ocidental. É preciso superar essa mera exigência formal de divisão dos poderes.

Um sistema de controle do poder, como forma de tornar efetivas as limitações impostas na Constituição, parece ser hoje inerente ao Estado Democrático de Direito, onde se pretende garantir as liberdades individuais, num regime político que visa a assegurar um mínimo de igualdade social, sem a qual as liberdades formais não passam de peça ilustrativa. Assegurar, assim, a intervenção e regulação exercidas pelo Estado para cumprir suas tarefas no mundo atual exige que haja permanente controle de todos os detentores do poder político, ainda que os modelos de controle diferenciemse em razão do poder que se exerce e do órgão que exerce o controle. De fato, as modificações do Estado decorrentes do fenômeno da globalização e a conseqüente diminuição do poder de conformação das instâncias estatais exigem mudanças no aparelhamento e no desempenho das funções estatais, sem que se possa, contudo, abdicar do permanente controle dos poderes políticos. A eficiência exigida pelos mercados e pelo controle democrático dos agentes públicos há de conjugar-se com a juridicidade, sob pena de perder-se toda a herança de conquistas advindas desde o estabelecimento do Estado de Direito. Como afirma Cláudio Pereira de Souza Neto, a imposição de cooperação e a previsão de interpenetração de tarefas na Constituição não desvirtua a separação de poderes, antes a incrementa, na medida em que as limitações entre os poderes são aprofundadas. A noção a preservar-se, portanto, é a de que:

Não há, portanto, uma separação estanque das funções estatais, mas uma ampla e intrincada rede de implicações recíprocas, a qual tem como objeto evitar o arbítrio, eventualmente decorrente de uma concentração excessiva do poder. ${ }^{162}$

Mudanças legislativas ou constitucionais que visem a aprimorar tal sistema são bem-vindas, como foram os casos do Conselho Nacional de Justiça e do Conselho Nacional do Ministério Público, ainda que, na atuação prática recente de tais instituições seu trabalho possa ser criticado. Afinal, a organização dos poderes imposta na Constituição Federal é uma obra 161 CASTRO, Flávia Viveiros de. Op. cit., p. 134.

162 SOUZA NETO, Cláudio Pereira. Teoria constitucional...p.33. 
humana, que merece retoques em decorrência da exposição da fórmula à realidade dos fatos.

Resta reconhecer, por fim, que o sistema de controle do poder, não obstante a variabilidade que pode assumir nos diferentes sistemas jurídicos nacionais, também não se constitui em uma fórmula mágica, capaz de assegurar as liberdades, a democracia e a igualdade. De fato, a simples previsão normativa de um sistema de controle das instituições políticas não assegura, por si só, o resultado aqui propugnado. Parece hoje a única possibilidade técnica de se garantir o funcionamento justo de uma democracia, mas boa parte de seu funcionamento dependerá que quem governa o país, de quem exerce o controle do poder, o que inclui a própria sociedade. Vale citar, pois, o que escreve Christian Delacampagne: "Mas as estruturas legais, por melhores que sejam, nem sempre bastam para proteger a democracia. É preciso, ainda, que os homens queiram jogar o jogo." 163

Se essa afirmação pode nos levar a um sentimento de frustração, em virtude da realidade da política brasileira dos últimos anos, há que se reconhecer, de outro lado, os enormes avanços do país no campo institucional, consolidando um sistema de eleições confiável, a liberdade de imprensa, a amplitude do poder de investigação das polícias e também do Ministério Público, um progressivo amadurecimento dos Tribunais de Contas, sucessivas instalações de comissões parlamentares de inquérito, e até a formação de grupos de pressão na sociedade para exigir ações públicas especificas, o que demonstra que o poder político hoje é controlado em nosso país, e se há defeitos - e ainda existem muitos - a solução é a continuação da caminhada institucional. É preciso afastar a idéia de soluções simplistas e voluntaristas, que sob o manto da justiça social ou da transformação das estruturas termina por violar as liberdades individuais e desmerecer o próprio processo democrático, esfacelando qualquer veio de legitimidade. Para isso, parece necessário o aperfeiçoamento da legislação, possíveis emendas constitucionais pontuais, e, sobretudo, contínua prática democrática, na medida em que, como ressalta Nelson Saldanha, as realizações culturais de um povo não correspondem apenas a vocações e intenções, mas também a chances e necessidades ${ }^{164} \mathrm{e}$ a construção de uma sociedade justa e igualitária, com democracia e liberdade, exige um processo contínuo, com avanços e recuos, e com um destino aberto a opções políticas consistentes com a deliberação democrática.

163 Op. cit., p. 58.

164 O Estado moderno...p. 91. 
Assim como a idéia de uma divisão de poderes já passou a integrar o conceito de uma constituição na contemporaneidade, a ela se associa - de forma complementar, mas necessária - a idéia de um sistema de controle das limitações do poder, pois se existe uma verdade que as diversas críticas ao liberalismo político não conseguiram afastar é a de que o funcionamento da democracia exige o pleno exercício das liberdades dos cidadãos, o que, por sua vez, só pode se verificar com um permanente sistema de controle do poder.

\section{Referências Bibliográficas}

ARAGON, Manuel. Constitución y control del poder. Buenos Aires: Ciudad Argentina, 1995.

BACHOF, Otto. Jueces y constitución. Trad. Rodrigo Bercovitz RodriguezCano, 1 ed., reimp. Madrid: Civitas, 1987.

BASTOS, Celso Ribeiro. Curso de teoria do Estado e ciência política. 5 ed. São Paulo: Celso Bastos Editor, 2002.

BINENBOJM, Gustavo. A Nova jurisdição constitucional brasileira: legitimidade democrática e instrumentos de realização. Rio de Janeiro: Renovar, 2001.

BOBBIO, Norberto. Locke e o direito natural. Trad. Sérgio Bath. 2 ed., Brasília: Universidade de Brasília, 1997.

- Teoria Geral da Política. (org. Michelangelo Bovero). Rio de Janeiro: Campus, 2000.

BONAVIDES, Paulo. Ciência política. 12 ed., São Paulo: Malheiros, 2006.

. Curso de direito constitucional. 9 ed., São Paulo: Malheiros, 2000.

CAETANO, Marcelo. Direito constitucional. Rio de Janeiro: Forense, 1977. vol. I.

CALSAMIGLIA, Albert. Ensayo sobre Dworkin. In: DWORKIN, Ronald. 
Los derechos es serio. Trad. Marta Guastavino. 1 ed., 3 reimp. Barcelona: Ariel, 1997. p.07-29.

CANOTILHO, J. J. Gomes. Direito constitucional e teoria da Constituição. 2 ed., Coimbra: Almedina, 1998.

CAPPELLETTI, Mauro. O Controle judicial de constitucionalidade das leis no direito comparado. Trad. Aroldo Plínio Gonçalves. Porto Alegre: Sérgio Antônio Fabris Editor, 1984.

CASTRO, Flávia Viveiros de. O princípio da separação dos poderes. In: Manoel Messias Peixinho; Isabella Franco Guerra; Firly Nascimento Filho (orgs.). Os Princípios da Constituição de 1988. 2 ed., Rio de Janeiro: Lumen Juris, 2006, p.133-145.

COOLEY, Thomas M.. Princípios gerais de direito constitucional nos Estados Unidos da América. Trad. Ricardo Rodrigues Gama. Campinas: Russel, 2002.

DELACAMPAGNE, Christian. A Filosofia política hoje: idéias, debates, questões. Trad. Lucy Magalhães. Rio de Janeiro: Jorge Zahar, 2001.

DINAMARCO, Cândido Rangel. A Instrumentalidade do processo. 4 ed., São Paulo: Malheiros, 1994.

ENTERRÍA, Eduardo Garcia de. La Constitución como norma y el tribunal constitucional. 3 ed., 3 reimp. Madrid: Civitas, 1994.

FARIAS, José Fernando de Castro. A Teoria do Estado no fim do século XIX e no início do século XX. - Os enunciados de Léon Duguit e de Maurice Hariou. Rio de Janeiro: Lumen Juris, 1999.

FAVOREAU, Louis. As Cortes constitucionais. Trad. Dunia Marinho Silva. São Paulo: Landy, 2004.

FIGUEIREDO, Fran. Metodologia constitucional. Brasília: Itamarati, 1987.

FRIEDRICH, Carl J.. Uma Introdução à teoria política. Trad. Leônidas Xausa e Luiz Corção. Rio de Janeiro: Zahar, 1970. 
GOYARD-FABRE, Simone. O Que é democracia. Trad. Claudia Berliner. São Paulo: Martins Fontes, 2003.

. Os Princípios filosóficos do direito político moderno. Trad. Irene A. Paternot. São Paulo: Martins Fontes, 1999.

HEGEL, Georg Friedrich. Princípios da filosofia do direito. Trad. Orlando Vitorino. Lisboa: Guimarães, 1990.

JACQUES, Paulino. Curso de direito constitucional. 5 ed., Rio de Janeiro: Forense, 1967.

JELLINEK, Georg. Reforma y mutacion de la Constitucion. Trad. Christian Förster. Madrid: Centro de Estudios Constitucionales, 1991.

KELSEN, Hans. Teoria geral do direito e do Estado. Trad. Luís Carlos Borges. 2 ed., 1 reimp. São Paulo: Martins Fontes, 1995.

. Teoria pura do direito. Trad. João Baptista Machado. 6 ed. São Paulo: Martins Fontes, 1998.

KIMMINICH, Otto. Jurisdição constitucional e princípio da divisão de poderes. Revista de Direito Público. São Paulo, n 92, p.17-33, 1989.

LARENZ, Karl. Derecho justo: fundamentos de etica jurídica. Trad. Luis Díez-Picazo. 1 ed. reimp. Madrid: Civitas, 1993.

LOCKE, John. Segundo tratado sobre o governo. 2 ed., São Paulo: Abril Cultural, 1978. (Coleção Os Pensadores).

LOPES, Júlio Aurélio Vianna. A Invasão do direito: a expansão jurídica sobre o Estado, o mercado e a moral. Rio de Janeiro: FGV, 2005.

LOWENSTEIN, Karl. Teoria de la Constitucion. Trad. Alfredo Gallego Anabitarte. 2 ed. Barcelona: Ariel, 1976.

MCILWAIN, Charles Howard. Constitucionalismo antiguo y moderno. Trad. Juan José Solozábal Echavarría. Madrid: Centro de Estudios Constitucionales, 1991. 
MEDAUAR, Odete. Controle da administração pública. São Paulo: Revista dos Tribunais, 1993.

MIRANDA, Jorge. Teoria do Estado e da Constituição. Rio de Janeiro: Forense, 2002.

MONTESQUIEU, Barão de la Brède e de [Charles-Louis de Secondat]. Do espírito das leis. São Paulo: Abril Cultural, 1973. (Coleção Os Pensadores)

MORAIS FILHO, José Filomeno. Separação de poderes no Brasil pós88: princípio constitucional e práxis política." In: SOUZA NETO, Cláudio Pereira et al. Teoria da Constituição: estudos sobre o lugar da política no direito constitucional. Rio de Janeiro: Lúmen Juris, 2003 p. p.151-199.

MOREIRA NETO, Diogo de Figueiredo. Poder, organização política e Constituição: as relações de poder em evolução e seu controle. In: TÔRRES, Heleno Taveira (coord). Direito e Poder: nas instituições e nos valores do público e do privado contemporâneos. Estudos em homenagem a Nelson Saldanha. São Paulo: Manole, 2005.

NEVES, Marcelo. A constitucionalização simbólica: uma síntese. Boletim da Faculdade de Direito da Universidade de Coimbra. Coimbra, p.99-131, 2000 .

PALOMBELLA, Gianluigi. Filosofia do direito. Trad. Ivone C. Benedetti. São Paulo: Martins Fontes, 2005.

SALDANHA, Nelson. O Estado moderno e a separação de poderes. São Paulo: Saraiva, 1987.

. Formação da teoria constitucional. Rio de Janeiro: Renovar, 2000.

SCHMITT, Carl. Teoría de la Constitución. Trad. Francisco Ayala. 1 ed., 2 reimp. Madrid: Alianza, 1996.

SILVA, José Afonso da. Curso de direito constitucional positivo. 23 ed. São Paulo: Malheiros, 2004.

SOUZA NETO, Cláudio Pereira de. Jurisdição constitucional, democracia e 
racionalidade prática. Rio de Janeiro: Renovar, 2002.

Teoria constitucional e democracia deliberativa: um estudo sobre o papel do direito na garantia das condições para a cooperação na deliberação democrática. Rio de Janeiro: Renovar, 2006.

TEIXEIRA, J. H. Meirelles. Curso de direito constitucional. Maria Garcia (org.) Rio de Janeiro: Forense Universitária, 1991.

TEMER, Michel. Elementos de direito constitucional. 11 ed. São Paulo: Malheiros, 1995. 